\title{
Toxicity of fluoride: critical evaluation of evidence for human developmental neurotoxicity in epidemiological studies, animal experiments and in vitro analyses
}

\author{
Sabine Guth ${ }^{1} \cdot$ Stephanie Hüser ${ }^{1} \cdot$ Angelika Roth $^{1} \cdot$ Gisela Degen $^{1} \cdot$ Patrick Diel $^{2} \cdot$ Karolina Edlund $^{1}$. \\ Gerhard Eisenbrand $^{3} \cdot$ Karl-Heinz Engel $^{4} \cdot$ Bernd Epe $^{5} \cdot$ Tilman Grune $^{6} \cdot$ Volker Heinz $^{7}$. Thomas Henle ${ }^{8}$. \\ Hans-Ulrich Humpf ${ }^{9} \cdot$ Henry Jäger $^{10} \cdot$ Hans-Georg Joost ${ }^{11}$. Sabine E. Kulling ${ }^{12}$. Alfonso Lampen ${ }^{13} \cdot$ Angela Mally $^{14}$. \\ Rosemarie Marchan ${ }^{1}$. Doris Marko ${ }^{15}$. Eva Mühle ${ }^{1}$. Michael A. Nitsche ${ }^{16,17}$. Elke Röhrdanz ${ }^{18}$. Richard Stadler ${ }^{19}$. \\ Christoph van Thriel ${ }^{1}$. Stefan Vieths ${ }^{20} \cdot$ Rudi F. Vogel $^{21} \cdot$ Edmund Wascher $^{22} \cdot$ Carsten Watzl $^{23}$. Ute Nöthlings ${ }^{24}$. \\ Jan G. Hengstler ${ }^{1}$
}

Received: 27 January 2020 / Accepted: 26 March 2020 / Published online: 8 May 2020

(c) The Author(s) 2020

\begin{abstract}
Recently, epidemiological studies have suggested that fluoride is a human developmental neurotoxicant that reduces measures of intelligence in children, placing it into the same category as toxic metals (lead, methylmercury, arsenic) and polychlorinated biphenyls. If true, this assessment would be highly relevant considering the widespread fluoridation of drinking water and the worldwide use of fluoride in oral hygiene products such as toothpaste. To gain a deeper understanding of these assertions, we reviewed the levels of human exposure, as well as results from animal experiments, particularly focusing on developmental toxicity, and the molecular mechanisms by which fluoride can cause adverse effects. Moreover, in vitro studies investigating fluoride in neuronal cells and precursor/stem cells were analyzed, and 23 epidemiological studies published since 2012 were considered. The results show that the margin of exposure (MoE) between no observed adverse effect levels (NOAELs) in animal studies and the current adequate intake (AI) of fluoride ( $50 \mu \mathrm{g} / \mathrm{kg} \mathrm{b.w./day)} \mathrm{in} \mathrm{humans} \mathrm{ranges} \mathrm{between} 50$ and 210 , depending on the specific animal experiment used as reference. Even for unusually high fluoride exposure levels, an MoE of at least ten was obtained. Furthermore, concentrations of fluoride in human plasma are much lower than fluoride concentrations, causing effects in cell cultures. In contrast, 21 of 23 recent epidemiological studies report an association between high fluoride exposure and reduced intelligence. The discrepancy between experimental and epidemiological evidence may be reconciled with deficiencies inherent in most of these epidemiological studies on a putative association between fluoride and intelligence, especially with respect to adequate consideration of potential confounding factors, e.g., socioeconomic status, residence, breast feeding, low birth weight, maternal intelligence, and exposure to other neurotoxic chemicals. In conclusion, based on the totality of currently available scientific evidence, the present review does not support the presumption that fluoride should be assessed as a human developmental neurotoxicant at the current exposure levels in Europe.
\end{abstract}

Keywords Sodium fluoride $\cdot$ Developmental neurotoxicity $\cdot$ Epidemiological studies $\cdot$ Animal studies $\cdot$ In vitro data $\cdot$ Risk assessment

Sabine Guth, Stephanie Hüser and Angelika Roth contributed equally to this publication.

Ute Nöthlings and Jan G. Hengstler are co-senior authors.

Electronic supplementary material The online version of this article (https://doi.org/10.1007/s00204-020-02725-2) contains supplementary material, which is available to authorized users.

Extended author information available on the last page of the article

\section{Introduction}

Since the 1940s, fluoride has been added to drinking water in many countries to reduce dental caries. Since then, the benefits and risks of fluoride remain among the most frequently discussed topics in the field of public health. This high interest is illustrated by the number of articles retrieved from a PubMed search (January 2019), which yielded 1416 articles for the keywords 'fluoride AND toxicity' since 
2000, and 472 articles published since 2015. In recent years, the possible adverse health effects of fluoride have gained attention as indicated by the increased number of scientific publications and reports from different media outlets, some of which highly recommend to not 'take up any fluoride, particularly not during pregnancy'. Some extreme examples, but also examples of balanced and objective reports, are documented in Online Resource 1. Frequently included in many reports is the statement that one of the world's leading medical journals now 'officially assessed fluoride as a human developmental neurotoxicant'. In this context, an article published in Lancet Neurology is often used as a reference, in which the authors claim that since 2006, epidemiological studies have documented additional human developmental neurotoxicants, among them fluoride, which apparently should now be placed in the same category as toxic metals (lead, methylmercury, arsenic) and polychlorinated biphenyls (Grandjean and Landrigan 2014). Moreover, further epidemiological publications - usually with a crosssectional study design - report an association between high exposure to fluoride via drinking water and low intelligence. In the present article, we reviewed the available literature to critically evaluate the human health hazards caused by exposure to fluoride, particularly focusing on developmental toxicity. Epidemiological studies, animal experiments and in vitro studies were considered to provide this comprehensive assessment.

\section{Toxicity of fluoride: the basics}

\section{Occurrence}

Fluoride $\left(\mathrm{F}^{-}\right)$is an inorganic anion that naturally occurs in minerals, particularly in fluorite $\left(\mathrm{CaF}_{2}\right)$. Fluoride salts are highly soluble and found ubiquitously in water, varying widely in concentration. For example, the levels in surface water are usually below $0.5 \mathrm{mg} / \mathrm{L}$, while much wider ranges $(0.1$ and $6 \mathrm{mg} / \mathrm{L}$ ) have been reported in groundwater (EFSA 2013). Depending on the presence of certain minerals, concentrations greater than $10 \mathrm{mg} / \mathrm{L}$ have been observed; however, such high concentrations are rare. Seawater also contains fluoride, but within a relatively narrow range between 1.2 and $1.5 \mathrm{mg} / \mathrm{L}$ (EFSA 2013).

\section{Absorption, excretion, and accumulation}

Soluble fluorides, e.g., sodium fluoride (NaF), are almost completely absorbed from the gastrointestinal tract into the blood (Barbier et al. 2010; EFSA 2005), with peak plasma levels attained within 20-60 min after oral ingestion (EFSA 2005; Whitford et al. 2008). Uptake may however be reduced by the formation of insoluble complexes or precipitates with food components. The presence of calcium in milk, for example, reduces systemic absorption. Fluoride is able to cross biological membranes by diffusion as the non-ionic hydrogen fluoride (HF) (Gutknecht and Walter 1981). The pKa of HF is approximately 3.4; therefore, more of the nonionic $\mathrm{HF}$ is present in acidic rather than in alkaline compartments (Buzalaf and Whitford 2011; Whitford 1996). The largest amount of absorbed fluoride is retained in bone and teeth (ATSDR 2003), where about $99 \%$ of the total fluoride in an organism are found (Ekstrand et al. 1977). In rats, the ratio of fluoride in soft tissues to plasma ranges between 0.4 and 0.9 (Whitford et al. 1979); reviewed by EFSA (EFSA 2013). However, the blood-brain barrier has a relatively low permeability, leading to ratios of approximately 0.1 between brain tissue and plasma. In contrast, the kidney may contain higher fluoride concentrations compared to plasma (Taves et al. 1983). Fluoride has also been reported to cross the placenta, and early reports have indicated that supplements of $1.5 \mathrm{mg}$ fluoride/day may increase fetal blood concentrations approximately twofold (Caldera et al. 1988; Shen and Taves 1974). Finally, most of the absorbed fluoride is excreted by the kidney, and only a smaller fraction via the feces (Villa et al. 2010).

\section{Mechanisms of action}

Fluoride interacts with proteins, particularly enzymes, and usually inhibits enzyme activity at concentrations in the millimolar range (Barbier et al. 2010; Mendoza-Schulz et al. 2009). However, cell proliferation may be stimulated at concentrations in the micromolar range (Adamek et al. 2005; Mendoza-Schulz et al. 2009). Whether fluoride has an essential function in cells or organisms is not known. The mechanisms by which fluoride affects cell functions include the generation of superoxide anions (Garcia-Montalvo et al. 2009; Izquierdo-Vega et al. 2008); mitochondrial toxicity, e.g., opening of the transition pore (Anuradha et al. 2001); release of cytochrome $\mathrm{c}$ from mitochondria and induction of apoptosis (Chlubek et al. 2003; Lee et al. 2008); inhibition of migration, e.g., of embryonic neurons (Horgan et al. 1994) and sperm (Izquierdo-Vega et al. 2008); increased endoplasmic reticulum stress in ameloblasts, the cell type responsible for enamel formation (Kubota et al. 2005); increased expression of inflammatory factors, such as NF-kappaB (Zhang et al. 2008) and IL-8 (Schwarze et al. 2000); and the modified release of the neurotransmitters acetylcholine (Flora et al. 2009) and gamma-aminobutyric acid (Gardiner and de Belleroche 1990).

At high doses, $\mathrm{NaF}$ has been shown to affect the immune system in mice (Guo et al. 2017). Doses higher than $12 \mathrm{mg} / \mathrm{kg}$ $\mathrm{NaF}$ resulted in a significant decrease in the percentages of $\mathrm{T}$ and $\mathrm{B}$ lymphocytes in peripheral blood. Moreover, a decrease in the serum concentration of the cytokines 
interleukin (IL)-2, IL-4, IL-6, IL-10, IL-17A, interferon (IFN)- $\gamma$, and tumor necrosis factor (TNF) was observed (Guo et al. 2017). In line with the reduction of B lymphocytes, NaF caused a decrease of antibody (IgA, IgG and IgM) concentrations in serum (Guo et al. 2017).

Specific molecular targets for most of the effects of fluoride remain to be established and many of the findings from in vitro studies were only observed in the millimolar range. Examples include studies with human pulmonary epithelial cells, human hepatocellular carcinoma cells, rat hippocampal neurons, and mouse hepatocytes, where fluoride-induced effects (e.g., induction of cyclooxygenase 2, p53, heat shock protein 70 , NF-kappaB, decrease of glutathione) were observed at 2.1, 3, 5, and $100 \mathrm{mM}$, as reviewed by Barbier et al. (Barbier et al. 2010). The in vivo relevance of such concentrations in humans is questionable, since fluoride plasma concentrations in healthy adults generally range between 0.4 and $3.0 \mu \mathrm{M}$ and it is likely that the soft tissue concentration is even lower (Fig. 1). Furthermore, even in patients with dental and skeletal fluorosis (see below), concentrations usually do not increase more than 20-fold above these reference levels (EFSA 2005). However, some of the effects on dental and skeletal cells identified in vitro were obtained using close to in vivo relevant concentrations. Examples include increased proliferation of ameloblasts (Yan et al. 2007), which was observed at micromolar fluoride concentrations, decreased expression of matrix metalloproteinase-20 in human ameloblasts $(10 \mu \mathrm{M})$, and increased expression of osteoclast differentiation factor in cultivated rat osteoblasts $(50 \mu \mathrm{M})$, as reviewed by Barbier et al. (Barbier et al. 2010).

\section{Positive health effects}

Currently, there is no known essential function for fluoride in cells and organisms. However, experimental studies to determine whether fluoride is indispensable are challenging, because it is difficult to completely avoid fluoride uptake. In one study, rats (F344) were kept under low-fluoride conditions $(2-23 \mu \mathrm{g} / \mathrm{kg}$ b.w./day) for several generations, which led to decreased weight gain (Schwarz and Milne 1972). In another study, supplementing fluoride to breastfed children in an area with low fluoride in the drinking water and breast milk was reported to significantly increase the height and weight of the children (Bergmann 1994). The preventive effect of fluoride against caries at $0.05 \mathrm{mg} / \mathrm{kg}$ b.w./day will

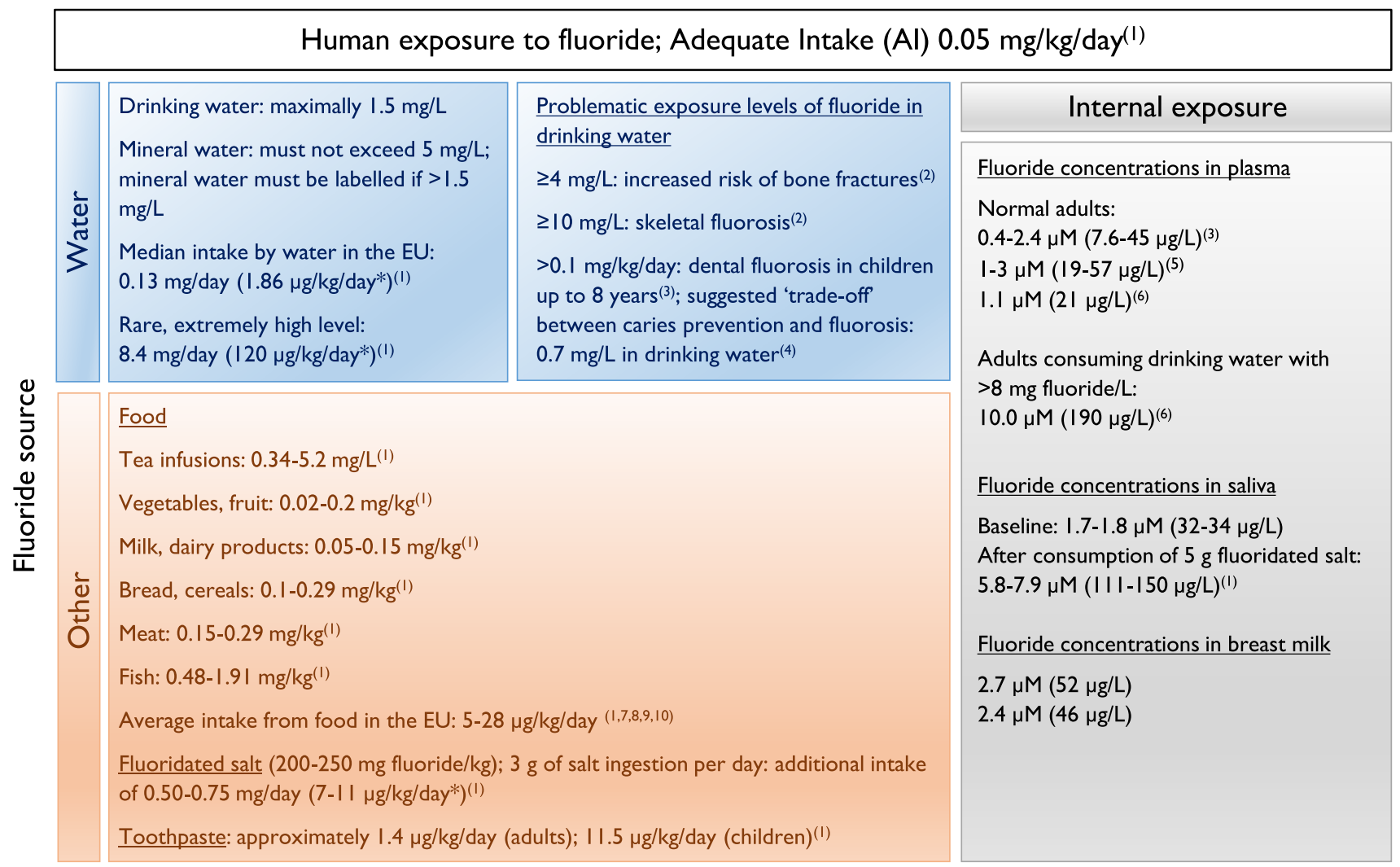

(1) EFSA, 2013; (2) NRC, 2006; (3) EFSA, 2005; (4) Heller et al., 1997; (5) Rugg-Gunn et al., 20I I; (6) Jha et al., 1982; (7)AFSSA, 2003;

(8) Taves, 1983; (9) Bergmann, 1994; (10) EVM, 200I; * adults with $70 \mathrm{~kg}$ b.w.

Fig. 1 Human exposure to fluoride 
be discussed below. Nevertheless, none of these observations proves an essential role for fluoride.

\section{Human exposure}

\section{Water}

The main source of human exposure to fluoride is water (EFSA 2013). The median fluoride intake via water and water-based beverages in EU countries is $0.13 \mathrm{mg} /$ day, which corresponds to $1.86 \mu \mathrm{g} / \mathrm{kg}$ b.w./day for an adult weighing $70 \mathrm{~kg}$ (Fig. 1). An extreme case is the intake of approximately $8.4 \mathrm{mg} /$ day $(120 \mu \mathrm{g} / \mathrm{kg}$ b.w./day for a person of $70 \mathrm{~kg}$ ), which was calculated based on the highest observed consumption ( 97.5 th percentile) of tap water and a fluoride concentration of $3 \mathrm{mg} / \mathrm{L}$ (EFSA 2013; SCHER 2011). According to the German drinking water ordinance, fluoride concentrations in tap water must not exceed $1.5 \mathrm{mg}$ fluoride/L. This value is only rarely exceeded and most samples of drinking water are below $0.3 \mathrm{mg}$ fluoride/L (BMG/UBA 2015; Schleyer and Kerndorf 1992). According to the European Commission Directive 2003/40/EC, the fluoride content of natural mineral water must not exceed $5 \mathrm{mg} / \mathrm{L}$, and it must be labeled if it contains more than $1.5 \mathrm{mg} / \mathrm{L}$. In Europe, fluoride is only added to drinking water in some regions of the UK, Spain, Portugal and Ireland. In the USA, the Environmental Protection Agency (EPA) recommends a concentration of $0.7 \mathrm{mg} / \mathrm{L}$ (PHS 2015).

\section{Food}

Food generally contains low fluoride concentrations in the range of $0.1-0.5 \mathrm{mg} / \mathrm{kg}$ (EFSA 2013). Typical amounts of fluoride in foods are depicted in Fig. 1. The fluoride content of both fish and meat depends on the care taken with deboning and can be as high as $5 \mathrm{mg} / \mathrm{kg}$ (EFSA 2013). Dried herbs, which are eaten in small amounts only, contain up to $2.0 \mathrm{mg}$ fluoride/ $\mathrm{kg}$ (EFSA 2013). Black and green tea may contain 170-400 mg fluoride per kg dry weight, with concentrations in tea infusions ranging between 0.34 and $5.2 \mathrm{mg} / \mathrm{L}$ (Chan and Koh 1996; Schmidt and Funke 1984). Finally, fluoridated salt contains 200-250 mg fluoride per kg, and on its own may contribute an additional fluoride intake of approximately $0.5-0.75 \mathrm{mg} /$ day $(7-11 \mu \mathrm{g} / \mathrm{kg}$ b.w./day for a person of $70 \mathrm{~kg}$ ) (EFSA 2013). The consumption of fluoridated salt differs between countries. In Switzerland and Germany, $\sim 85 \%$ and $\sim 67 \%$ of the domestic salt is fluoridated, whereas fluoridated salt is only rarely used in other European countries (Marthaler 2013). In Latin America, more than 100 million users of fluoridated salt were reported and in several countries around $90-99 \%$ coverage was achieved (Marthaler 2013).

\section{Exposure from dietary sources in Europe}

Reliable and representative data on the total fluoride intake of the European population are not available (EFSA 2013). In France, the intake of fluoride through food (water, toothpaste, and supplements excluded) was estimated to be about $2 \mathrm{mg} /$ day for adults $(29 \mu \mathrm{g} / \mathrm{kg}$ b.w./day for a person of $70 \mathrm{~kg})$ (AFSSA 2003). In the UK, the average total dietary fluoride intake of the adult population, including tea but excluding drinking water, was estimated from the 1997 Total Diet Study to be $1.2 \mathrm{mg} /$ day $(17 \mu \mathrm{g} / \mathrm{kg}$ b.w./day for a person of 70 kg) (EFSA 2013; EVM 2001). Earlier, a fluoride intake of $1.78 \mathrm{mg} /$ day from both food and beverages $(25 \mu \mathrm{g} / \mathrm{kg}$ b.w. for a person of $70 \mathrm{~kg}$ ) and of $0.4 \mathrm{mg} /$ day from foods only $(6 \mu \mathrm{g} / \mathrm{kg} \mathrm{b.w./day} \mathrm{for} \mathrm{a} \mathrm{person} \mathrm{of} 70 \mathrm{~kg}$ ) for adults in the UK had been estimated (EFSA 2013; Taves 1983). In Sweden, the fluoride intake of adults from food and beverages in areas with low fluoride concentrations in drinking water $(<0.4 \mathrm{mg} / \mathrm{L})$ was estimated to be $0.4-1.0 \mathrm{mg} / \mathrm{day}(6-14 \mu \mathrm{g} / \mathrm{kg}$ b.w./day for a person of $70 \mathrm{~kg}$ ), while in areas with fluoride concentrations of $1 \mathrm{mg} / \mathrm{L}$ in the water the mean intake was estimated to be $2.1-4.4 \mathrm{mg} /$ day $(30-63 \mu \mathrm{g} / \mathrm{kg}$ b.w./day for a person of $70 \mathrm{~kg}$ ) (Becker and Bruce 1981; EFSA 2013). In Germany, the dietary fluoride intake (solids and beverages) was estimated to be $0.379 \mathrm{mg} /$ day in adults $(5 \mu \mathrm{g} / \mathrm{kg}$ b.w./day for a person of $70 \mathrm{~kg}$ ) (Bergmann 1994; EFSA 2013). This intake was increased considerably when a high fluoride concentration of $1 \mathrm{mg} / \mathrm{L}$ in drinking water was present or fluoridated salt was used ( $0.25 \mathrm{mg}$ fluoride per gram of salt) (Bergmann 1994; EFSA 2013).

Recently, a total diet study on fluoride intake in Ireland that considered exposure from foods, beverages, and fluoridated water was carried out among children aged 1-12 years, as well as in adults (FSAI 2018). Mean fluoride exposures among preschool children (1-4 years of age) and children (5-12 years of age) were 23 and $17 \mu \mathrm{g} / \mathrm{kg}$ b.w./day, respectively, which were lower than levels measured in adults ( $40 \mu \mathrm{g} / \mathrm{kg}$ b.w./day). The higher exposure of adults was predominantly due to fluoride consumption by black tea that contributed approximately $76 \%$ of the total exposure.

Overall, the average exposure in European areas with low fluoride in drinking water was estimated to be in the range of $5-14 \mu \mathrm{g} / \mathrm{kg}$ b.w./day, whereas in areas with high fluoride in drinking water an average exposure of approximately 30-40 $\mu \mathrm{g} / \mathrm{kg}$ b.w./day (maximum: $63 \mu \mathrm{g} / \mathrm{kg}$ b.w./day) was estimated. Therefore, the mean intake of fluoride from food, water, and beverages generally was below the adequate intake (AI) level of $50 \mu \mathrm{g} / \mathrm{kg}$ b.w., which is recommended for caries protection for all age groups, and particularly for children. This level could slightly be exceeded in areas with high fluoride in drinking water $(\geq 1 \mathrm{mg} / \mathrm{L})$ and maximum intake levels. 


\section{Oral hygiene products}

Fluoride-containing toothpaste, gels, and rinses may increase total fluoride intake. Small children and some adults tend to swallow toothpaste, which has been estimated to add between 0.016 and $0.15 \mathrm{mg}$ fluoride uptake per cleaning procedure (EFSA 2013). Toothpaste can account for up to $25 \%$ of the total systemic dose for children aged between 2 and 6 years, depending on the amount of toothpaste swallowed during brushing (SCHER 2011). The average intake of fluoride from toothpaste was estimated to be approximately $1.4 \mu \mathrm{g} / \mathrm{kg}$ b.w./day for adults and $11.5 \mu \mathrm{g} / \mathrm{kg}$ b.w./day for children (EFSA 2013).

\section{Biomarkers of body burden}

Fluoride concentrations in plasma are influenced by the current intake, with 0.4-3.0 $\mu \mathrm{M}$ being reported (IPCS 2002; Rugg-Gunn et al. 2011; Whitford 1996) (Fig. 1). Concentrations of fluoride in human plasma increase with the fluoride content in bone, with age, and as a consequence of renal insufficiency (Ekstrand and Whitford 1988). They may be up to 20-fold higher in individuals with skeletal and dental fluorosis (Jha et al. 1982). In breast milk, concentrations of $2.7 \mu \mathrm{M}(52 \mu \mathrm{g} / \mathrm{L})$ and $2.4 \mu \mathrm{M}(46 \mu \mathrm{g} / \mathrm{L})$ have been reported in fluoridated and non-fluoridated areas, respectively (Dirks et al. 1974; Ekstrand et al. 1981; Koparal et al. 2000). Baseline concentrations of fluoride in saliva have been reported to be 1.7-1.8 $\mu \mathrm{M}$ (EFSA 2013), which may increase to $5.8-7.9 \mu \mathrm{M}$ after consumption of approximately $5 \mathrm{~g}$ of fluoridated salt $(0.25 \mathrm{mg}$ fluoride per gram of salt).

\section{Human toxicity}

\section{Acute toxicity}

Symptoms due to toxicity include respiratory arrest, cardiac depression, vomiting, diarrhea, and salivation. In humans, lethal doses have been reported in the range of $40-80 \mathrm{mg} / \mathrm{kg}$ b.w. (Boink et al. 1994; Eichler et al. 1982; Lidbeck et al. 1943; Simpson et al. 1980; Whitford 1996). This knowledge stems from mass poisoning catastrophes. For example, in 1943, 163 prison inmates were accidentally poisoned resulting in 47 fatalities. In this unfortunate incident, eggs were accidentally prepared with cockroach powder containing sodium fluoride rather than the usual milk powder. Non-lethal overdosing has also been observed in the range of $0.4-5 \mathrm{mg} / \mathrm{kg}$ b.w. (for example, by accidental overdosing of caries prophylaxis tablets), and has been reported to cause nausea and gastrointestinal effects (Eichler et al. 1982; Whitford 1996).

\section{Dental and skeletal fluorosis}

One of the best documented long-term effects of fluoride in humans is dental fluorosis (EFSA 2005, 2013). Excessive fluoride incorporation into dental enamel before the eruption of teeth leads to hypomineralization of the developing teeth. Susceptibility to dental fluorosis ends at about 8 years of age when enamel maturation is completed. The risk of dental fluorosis should be evaluated in relation to the caries preventive effect of fluoride. Knowledge in this field stems from studies completed before 1980, when endemic fluoride in drinking water was the only relevant source of human fluoride intake (EFSA 2013). These studies demonstrated that the prevalence of caries was negatively correlated with the fluoride concentration in drinking water, with a maximal preventive effect at $1 \mathrm{mg} / \mathrm{L}$. At this fluoride concentration in drinking water, $10 \%$ of the study population exhibited mild dental fluorosis (EFSA 2013). Balancing the benefits of caries prevention against the risk of dental fluorosis, EFSA recommended an AI of $0.05 \mathrm{mg}$ fluoride $/ \mathrm{kg}$ b.w. per day from all sources for children and adults, including pregnant and lactating women (EFSA 2013). For adults, this fluoride intake is not exceeded with a drinking water concentration of approximately $1 \mathrm{mg} / \mathrm{L}$ fluoride, under conditions where drinking water is the only relevant source of fluoride. For children, however, the AI may just be reached, for example when a 6-year-old child weighing $20 \mathrm{~kg}$ drinks $1 \mathrm{~L}$ of water containing $1 \mathrm{mg}$ fluoride/L.

Skeletal fluorosis is a reversible effect characterized by deficient mineralization of the bone, leading to changes in bone structure and increased risk of fractures. Skeletal fluorosis is endemic in several countries where the potable water sources naturally contain high fluoride levels $(>4 \mathrm{mg} / \mathrm{L}$ ), and where water consumption is high due to hot climates (EFSA 2013). Fluoride intakes of above 6-8 mg/day may increase the risk of bone fractures (EFSA 2013; NHMRC 2017a; WHO 2011, 2017).

\section{Carcinogenicity}

A series of epidemiological studies addressed the question whether high fluoride in drinking water is associated with cancer mortality, but none reported a significant association (IARC 1982; Knox 1985). Studies on fluoride conducted in vitro and in vivo have reported some evidence of genotoxicity, but no causal link between high fluoride intake and increased human cancer risk was ever established (EFSA 2008).

\section{Reproductive and developmental toxicity}

Extremely high exposure to $38.5 \mathrm{mg}$ fluoride/L in drinking water was reported to be associated with infertility in men 
(Neelam et al. 1987). Furthermore, in recent years a relatively large number of studies have been published-as discussed in the next section-which reports that high fluoride intake is associated with reduced IQ in children.

\section{Studies with experimental animals}

To accurately interpret evidence of fluoride toxicity in humans obtained from epidemiological studies, we sought to compare known human exposure levels to NOAELs and LOAELs derived from experimental animal studies. Therefore, we reviewed animal studies that included acute and chronic toxicity data, as well as data on developmental, neurobehavioral, and reproductive toxicity (Fig. 2; Tables 1, 2, 3, $4,5)$. The $\mathrm{LD}_{50}$ (lethal dose $50 \%$ ) of sodium fluoride after oral administration ranges between 31 and $102 \mathrm{mg} / \mathrm{kg}$ b.w./day in rats (ATSDR 1993; IARC 1982), and between 26 and $94 \mathrm{mg} / \mathrm{kg}$ b.w./day in mice (IARC 1982; Whitford 1990). Thus, acute toxicity $\left(\mathrm{LD}_{50}\right)$ occurred between 26 and $102 \mathrm{mg} / \mathrm{kg}$ b.w./day, and chronic toxicity (LOAEL) between 4.3 and $7.6 \mathrm{mg} / \mathrm{kg}$ b.w./day fluoride (Fig. 2) (NRC 2006). Developmental toxicity from four comprehensive studiesselected because of their compliance to standard guidelines and the use of adequate numbers of animals (NRC 2006) — was found to be in a range between 11.4 and $12.7 \mathrm{mg} / \mathrm{kg} \mathrm{b.w./day}$ (LOAELs). In the following paragraphs, overviews of the available chronic, developmental, neurobehavioral, and reproductive toxicity studies are provided.

\section{Chronic toxicity}

A number of chronic toxicity studies that focused on systemic effects resulted in LOAELs in rats, mice, and rabbits ranging between 4.3 and $7.6 \mathrm{mg} / \mathrm{kg}$ b.w./day (Table 1). Adverse effects were observed in the respiratory, cardiovascular, gastrointestinal, hematological, hepatic, renal, and muscular/skeletal system, showing that fluoride can cause a wide range of systemic effects at the tested doses (Table 1). Interestingly, the NOAELs and LOAELs derived from the chronic toxicity studies were relatively similar among the three species.

\section{Developmental toxicity}

A comprehensive summary of studies published between 1990 and 2005 is provided in the National Research Council (NRC) report, demonstrating that developmental processes are susceptible to fluoride (NRC 2006). Four developmental toxicity studies are highlighted, because of their compliance to standard guidelines, adequate numbers of animals, and administration of sodium fluoride in drinking water. These studies resulted in NOAELs of $13.2 \mathrm{mg} / \mathrm{kg} \mathrm{b}$.w./day for rats (Heindel et al. 1996), $13.7 \mathrm{mg} / \mathrm{kg}$ b.w./day for rabbits (Heindel et al. 1996), $11.2 \mathrm{mg} / \mathrm{kg}$ b.w./day for rats (Collins et al. 1995), and 8.5-8.7 mg/kg b.w./day for rats (Collins et al. 2001b); (Table 2). While Heindel et al. (1996) found no adverse effects at doses up to $13.7 \mathrm{mg} / \mathrm{kg}$ b.w./day, Collins et al. reported a significant increase in the average number of fetuses with three or more skeletal variations at a dose of $11.4 \mathrm{mg} / \mathrm{kg}$ b.w /day (Collins et al. 1995) or decreased ossification of the hyoid bone of F2 fetuses at $11.7 \mathrm{mg} / \mathrm{kg}$ b.w./day (Collins et al. 2001b).

Since the report of the NRC, no further developmental studies conducted according to standard guidelines (OECD or NTP) have become available. A literature search from 2005 to 2018 revealed a number of animal studies that reported an effect of fluoride exposure during development on various end points in offsprings (excluding neurobehavioral effects which will be discussed in a separate paragraph), e.g., histopathological changes in the myocardial tissue (Bouaziz et al. 2007), induction of oxidative stress (Cicek
Fig. 2 Overview of animal studies with fluoride $\left(\mathrm{F}^{-}\right)$with regard to acute, chronic, developmental (Dev) and reproductive (Repro) toxicity

\begin{tabular}{|c|c|c|c|}
\hline & & $\begin{array}{c}\text { MoE (Al: } \\
50 \mu \mathrm{g} / \mathrm{kg} / \text { day) }\end{array}$ & $\begin{array}{l}\text { MoE (extreme: } \\
120 \mu \mathrm{g} / \mathrm{kg} / \text { day })\end{array}$ \\
\hline 苞 & $\begin{array}{l}\mathrm{LD}_{50} \text { (rats), oral administration: } \mathbf{3 1 - 1 0 2} \mathrm{mg} / \mathrm{kg} \text { b.w. } \\
\mathrm{LD}_{50} \text { (mice), oral administration: } 26-94 \mathrm{mg} / \mathrm{kg} \text { b.w. }\end{array}$ & $\begin{array}{l}620 \\
520\end{array}$ & $\begin{array}{l}258 \\
217\end{array}$ \\
\hline$\frac{0}{\frac{0}{2}}$ & $\begin{array}{l}\text { Selected studies investigating primarily systemic effects } \\
\text { NOAEL (rats, mice and rabbits): } 2.5-7.6 \mathrm{mg} / \mathrm{kg} / \mathrm{day} \\
\text { LOAEL (rats, mice and rabbits): } 4.3-7.6 \mathrm{mg} / \mathrm{kg} / \mathrm{day}\end{array}$ & $\begin{array}{l}50 \\
86\end{array}$ & $\begin{array}{l}21 \\
36\end{array}$ \\
\hline هั & 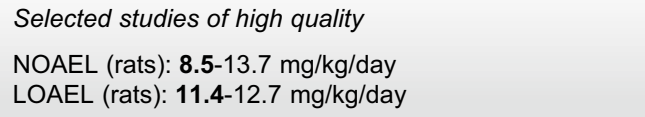 & $\begin{array}{l}170 \\
228\end{array}$ & $\begin{array}{l}71 \\
95\end{array}$ \\
\hline $\begin{array}{l}\frac{0}{0} \\
\frac{0}{\dddot{a}}\end{array}$ & $\begin{array}{l}\text { Selected studies of high quality } \\
\text { NOAEL (rats): } 10.5 \mathrm{mg} / \mathrm{kg} / \text { day }\end{array}$ & 210 & 88 \\
\hline
\end{tabular}


Table 1 Chronic toxicity studies; selected studies investigating primarily systemic effects

\begin{tabular}{|c|c|c|c|c|c|c|c|c|}
\hline $\begin{array}{l}\text { Species, strain, } \\
\text { number of } \\
\text { animals }\end{array}$ & $\begin{array}{l}\text { Exposure } \\
\text { duration, } \\
\text { chemical } \\
\text { form, route }\end{array}$ & $\begin{array}{l}\mathrm{NaF} \\
\text { concentration } \\
\text { in } \mathrm{DW}(\mathrm{mg} / \mathrm{L})\end{array}$ & $\begin{array}{l}\mathrm{NaF}_{\text {doses }}^{\mathrm{a}} \\
\text { (mg/kg b.w./ } \\
\text { day) }\end{array}$ & Effects & $\begin{array}{l}\text { NOAEL } \\
\mathrm{F}^{-} \\
\text {(mg/kg } \\
\text { b.w./day) }\end{array}$ & $\begin{array}{l}\text { LOAEL F}^{-} \\
(\mathrm{mg} / \mathrm{kg} \\
\text { b.w./day) }\end{array}$ & Comment & References \\
\hline $\begin{array}{l}\text { Rat } \\
\text { F-344 N } \\
\text { 50-80 sex/group }\end{array}$ & $\begin{array}{l}103 \text { weeks } \\
\text { Sodium } \\
\text { fluoride } \\
\text { (DW) }\end{array}$ & $\begin{array}{l}0,25,100, \\
175(0, \\
11.3,45.3, \\
79.3 \mathrm{mg} \\
\left.\mathrm{F}^{-} / \mathrm{L}\right) \\
\text { Control: deion- } \\
\text { ized water }\end{array}$ & $\begin{array}{l}0,1.3,5.2-5.5 \\
8.6-9.5 \\
\text { (correspond- } \\
\text { ing to } 0, \\
0.6,2.4-2.5 \\
3.9-4.3 \mathrm{mg} \\
\mathrm{F}^{-} / \mathrm{kg} \text { b.w./ } \\
\text { day) }\end{array}$ & $\begin{array}{l}\text { Resp, cardio, } \\
\text { gastro, hemato, } \\
\text { hepatic, renal, } \\
\text { bd wt } \\
\text { Musc/skel (osteo- } \\
\text { sclerosis) }\end{array}$ & 2.5 & 4.3 & $\begin{array}{l}\text { Diet: NIH-07 } \\
\text { low fluoride }\end{array}$ & NTP (1990) \\
\hline $\begin{array}{l}\text { Mouse } \\
\text { B6C3F1 } \\
\text { 50-80 sex/group }\end{array}$ & $\begin{array}{l}103 \text { weeks } \\
\text { Sodium } \\
\text { fluoride } \\
\text { (DW) }\end{array}$ & $\begin{array}{l}0,25,100, \\
175(0, \\
11.3,45.3, \\
79.3 \mathrm{mg} \\
\left.\mathrm{F}^{-} / \mathrm{L}\right) \\
\text { Control: deion- } \\
\text { ized water }\end{array}$ & $\begin{array}{l}\text { 0, 2.4-2.8, } \\
\text { 9.6-11.3, } \\
16.7-18.8 \\
\text { (corre- } \\
\text { sponding to } \\
0,1.1-1.3, \\
4.3-5.1, \\
7.6-8.5 \mathrm{mg} \\
\mathrm{F}^{-} / \mathrm{kg} \text { b.w./ } \\
\text { day) }\end{array}$ & $\begin{array}{l}\text { Resp, cardio, } \\
\text { gastro, hemato, } \\
\text { hepatic, renal, } \\
\text { bd wt } \\
\text { Musc/skel (den- } \\
\text { tine dysplasia) }\end{array}$ & $4.3, \mathrm{M}$ & 7.6 & $\begin{array}{l}\text { Diet: NIH-07 } \\
\text { low fluoride }\end{array}$ & NTP (1990) \\
\hline $\begin{array}{l}\text { Rabbit } \\
\text { 9/group }\end{array}$ & $\begin{array}{l}24 \text { month } \\
\text { Sodium } \\
\text { fluoride } \\
(\mathrm{GW})\end{array}$ & & $\begin{array}{l}10 \\
\text { (correspond- } \\
\text { ing to } \\
4.5 \mathrm{mg} \mathrm{F}^{-} / \mathrm{kg} \\
\text { b.w./day) }\end{array}$ & $\begin{array}{l}\text { Gastro (rough- } \\
\text { ened duodena } \\
\text { mucosa) }\end{array}$ & & 4.5 & $\begin{array}{l}\text { Standard } \\
\text { animal diet; } \\
\text { DW: fluo- } \\
\text { ride content } \\
\text { less than } \\
0.5 \mathrm{mg} / \mathrm{L}\end{array}$ & $\begin{array}{r}\text { Susheela and } \\
\text { Das (1988) }\end{array}$ \\
\hline $\begin{array}{l}\text { Rabbit } \\
\text { 5/group }\end{array}$ & $\begin{array}{l}\text { 7-12 month } \\
\text { Sodium } \\
\text { fluoride } \\
\text { (G) }\end{array}$ & & $\begin{array}{l}10 \\
\text { (corre- } \\
\text { sponding to } \\
4.5 \mathrm{mg} \mathrm{F}^{-} / \mathrm{kg} \\
\text { b.w./day) }\end{array}$ & $\begin{array}{l}\text { Hemato } \\
\text { (decreased } \\
\text { leucocyte and } \\
\text { hemoglobin } \\
\text { levels) }\end{array}$ & & 4.5 & & $\begin{array}{r}\text { Susheela and } \\
\text { Jain (1983) }\end{array}$ \\
\hline
\end{tabular}

$B d w t$ body weight, Cardio cardiovascular, $D W$ drinking water, $F$ females, $G$ gavage, Gastro gastrointestinal, GW gavage in water, Hemato hematological, LOAEL lowest-observed-adverse-effect level, $M$ males, $M u s c / s k e l$ muscular/skeletal, NaF sodium fluoride, NOAEL no-observedadverse-effect level, Resp respiratory

${ }^{\mathrm{a}}$ As reported by the authors

et al. 2005), histological lesions in testes, and abnormalities in testicular tissue (Zhang et al. 2013, 2016), and an influence on sperm parameters (Reddy et al. 2007). In part, these end points, e.g., the induction of oxidative stress or histopathology of the myocardium are not covered by the standard guidelines. Furthermore, fluoride exposure was shown to alter DNA methylation in early mouse embryos (Zhao et al. 2015; Zhu et al. 2014). The respective studies are quite heterogeneous with respect to experimental settings (e.g., animal model, dose levels) and end points examined. Overall, all studies reported lower NOAELs $(0.23-0.57 \mathrm{mg} / \mathrm{kg} /$ day $)$ and LOAELs (0.1-4.9 mg/kg/day) than the above summarized studies (Table 3 ). If the authors only reported fluoride concentrations in drinking water, the conversion into daily doses was performed by applying default conversion factors that were derived by EFSA (EFSA 2012) (Table 3). A review of the quality of these studies identified various limitations that hamper their interpretation and reduce their value for risk assessment. For example, the following aspects were often not adequately addressed:

(i) Characterization of the test compound, e.g., source, purity, and chemical form of fluoride

(ii) Randomization

(iii) Blinding of treatment and outcome assessment

(iv) Key study information, e.g., species/strain, gender, or number of animals used for treatment and composition of the animal die

(v) Experimental setting, e.g., outcome assessment, number of dose levels, and duration of treatment

(vi) Control for litter effects 


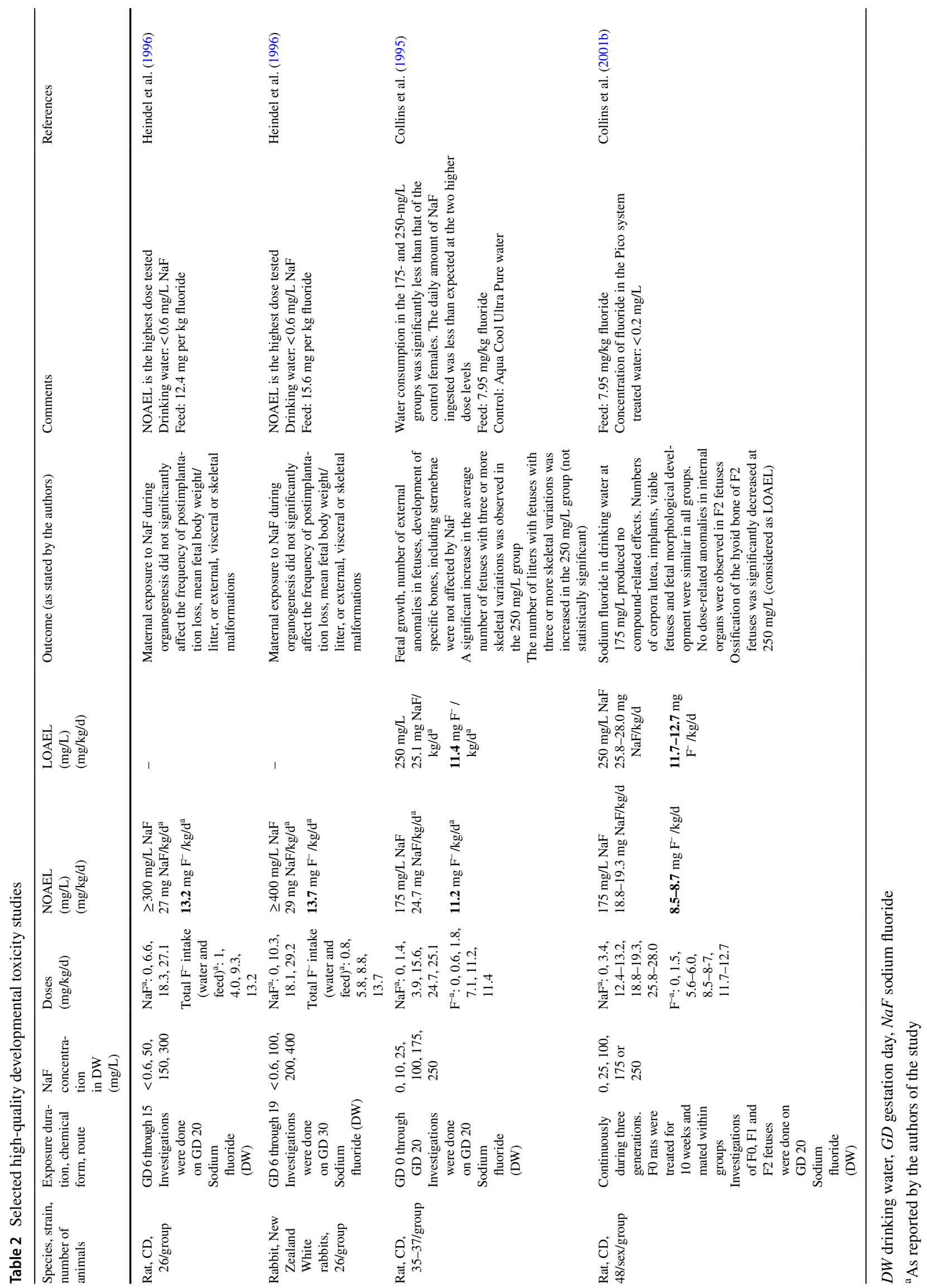




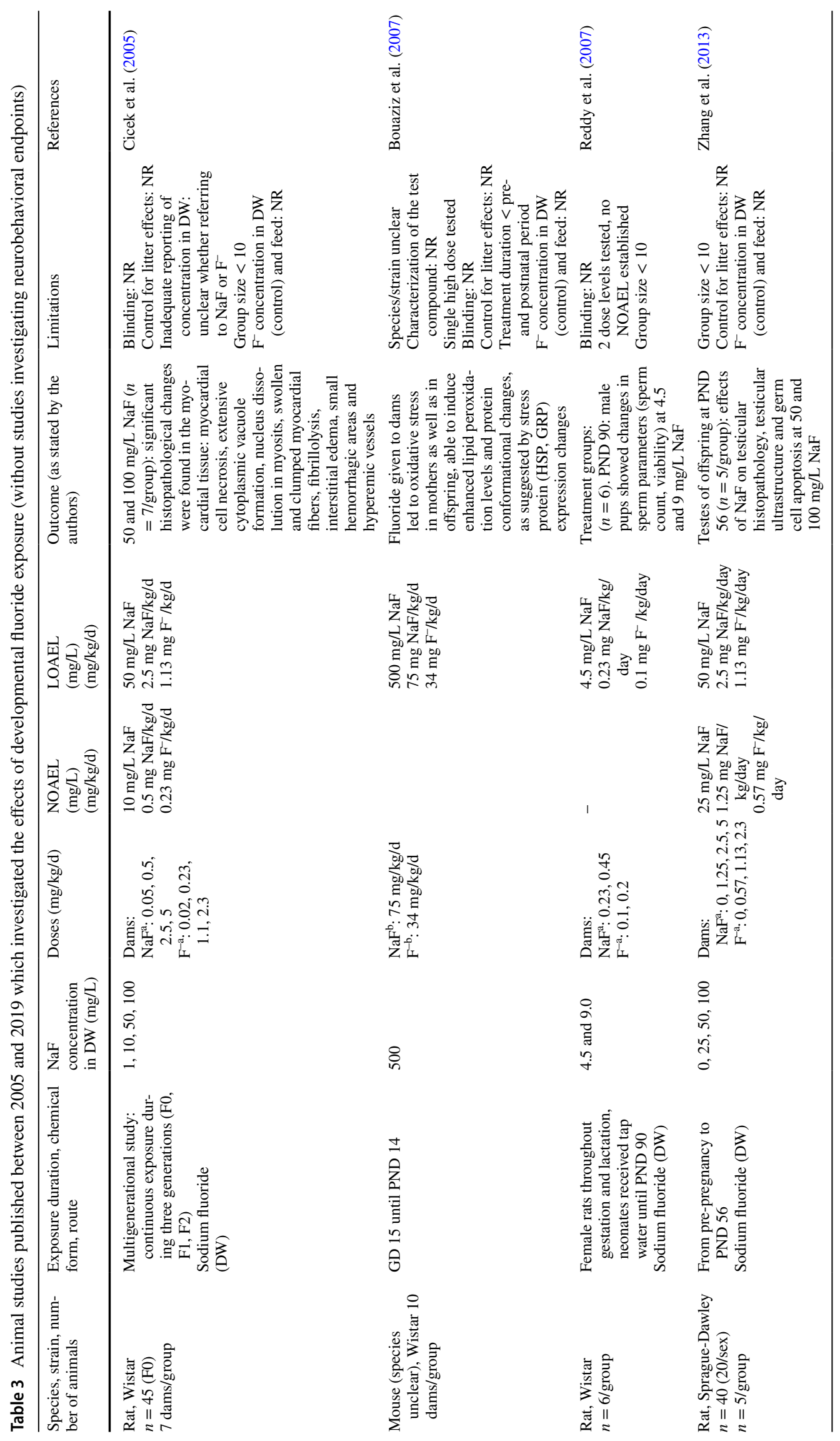




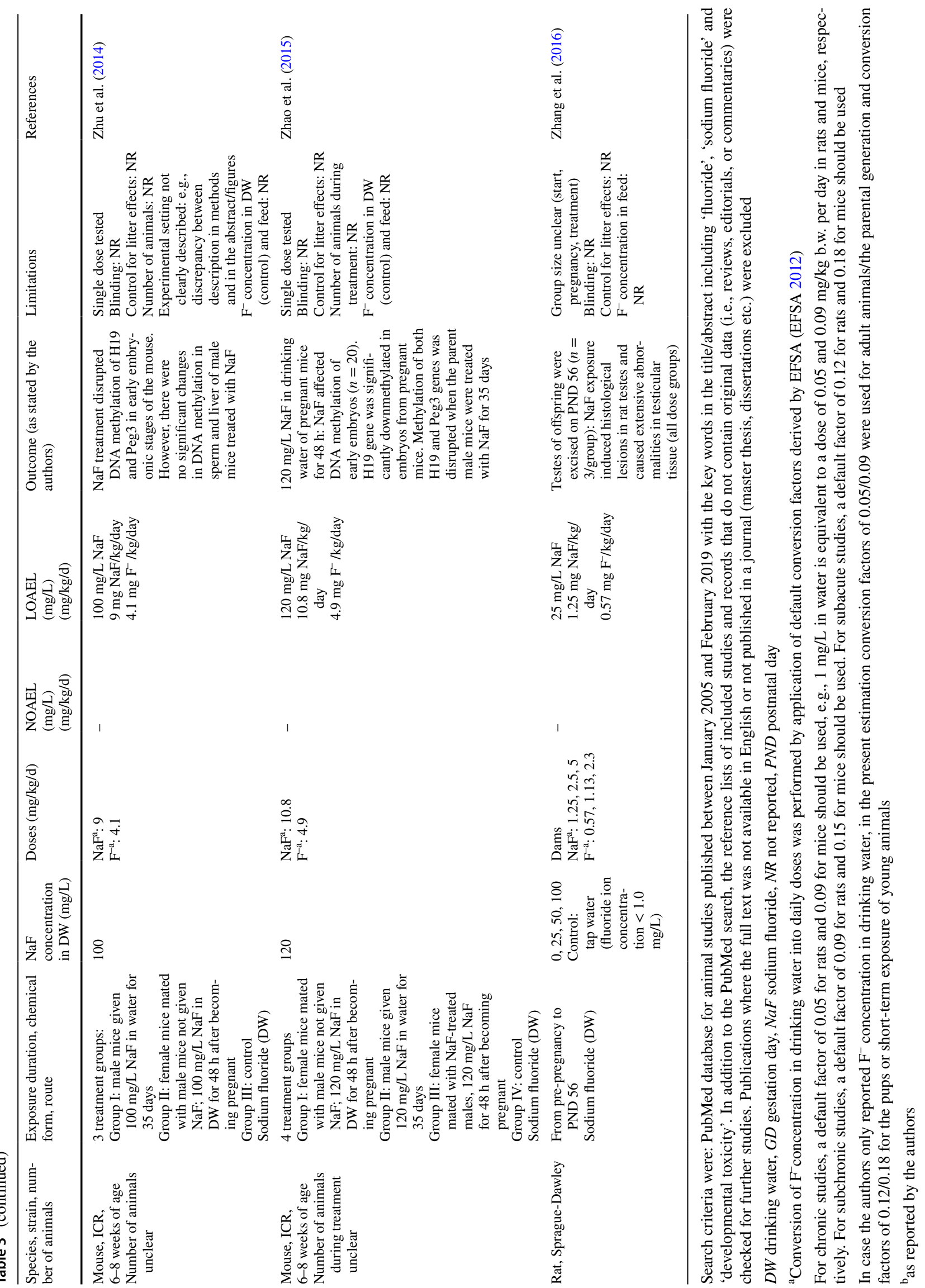




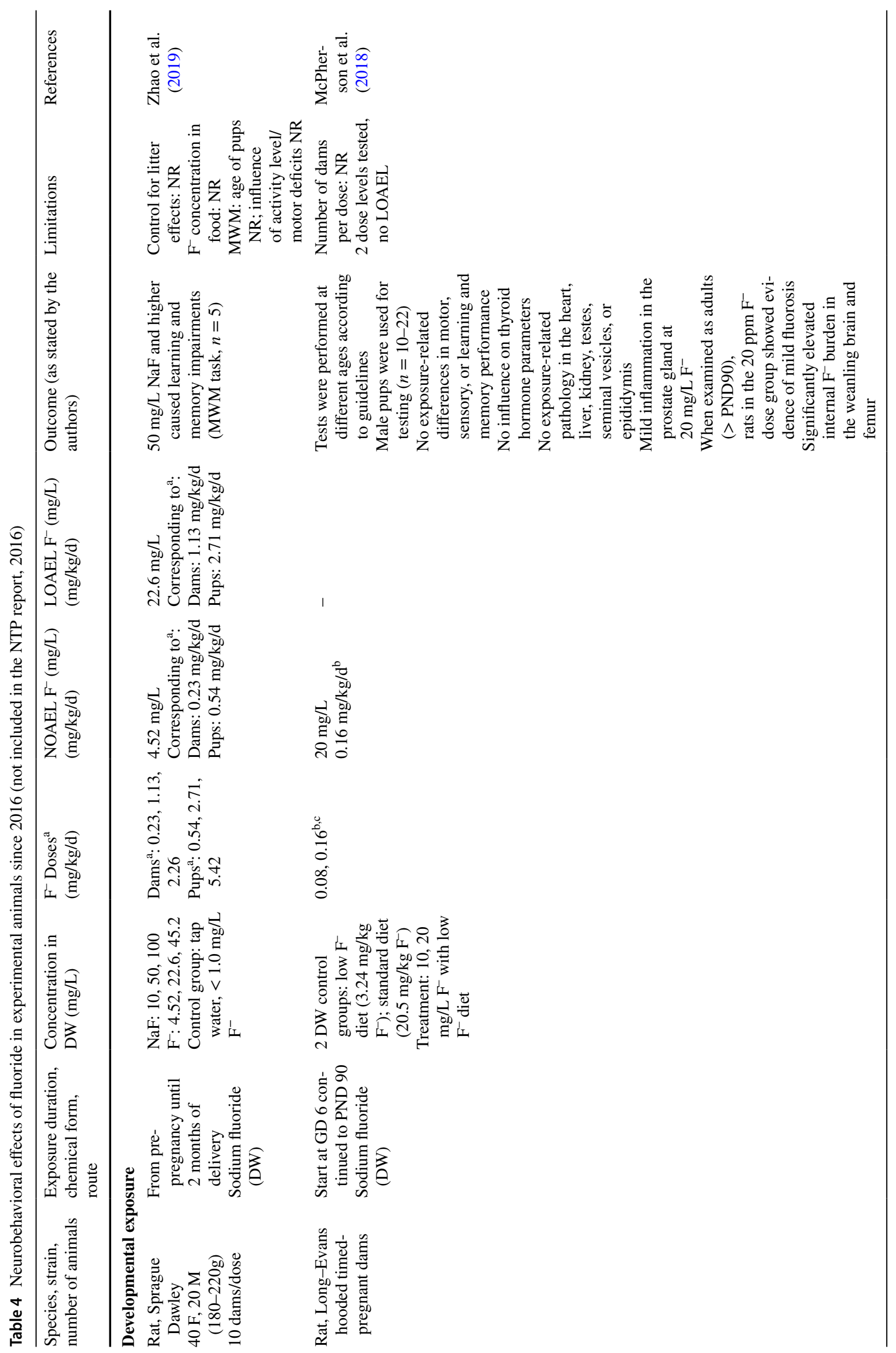




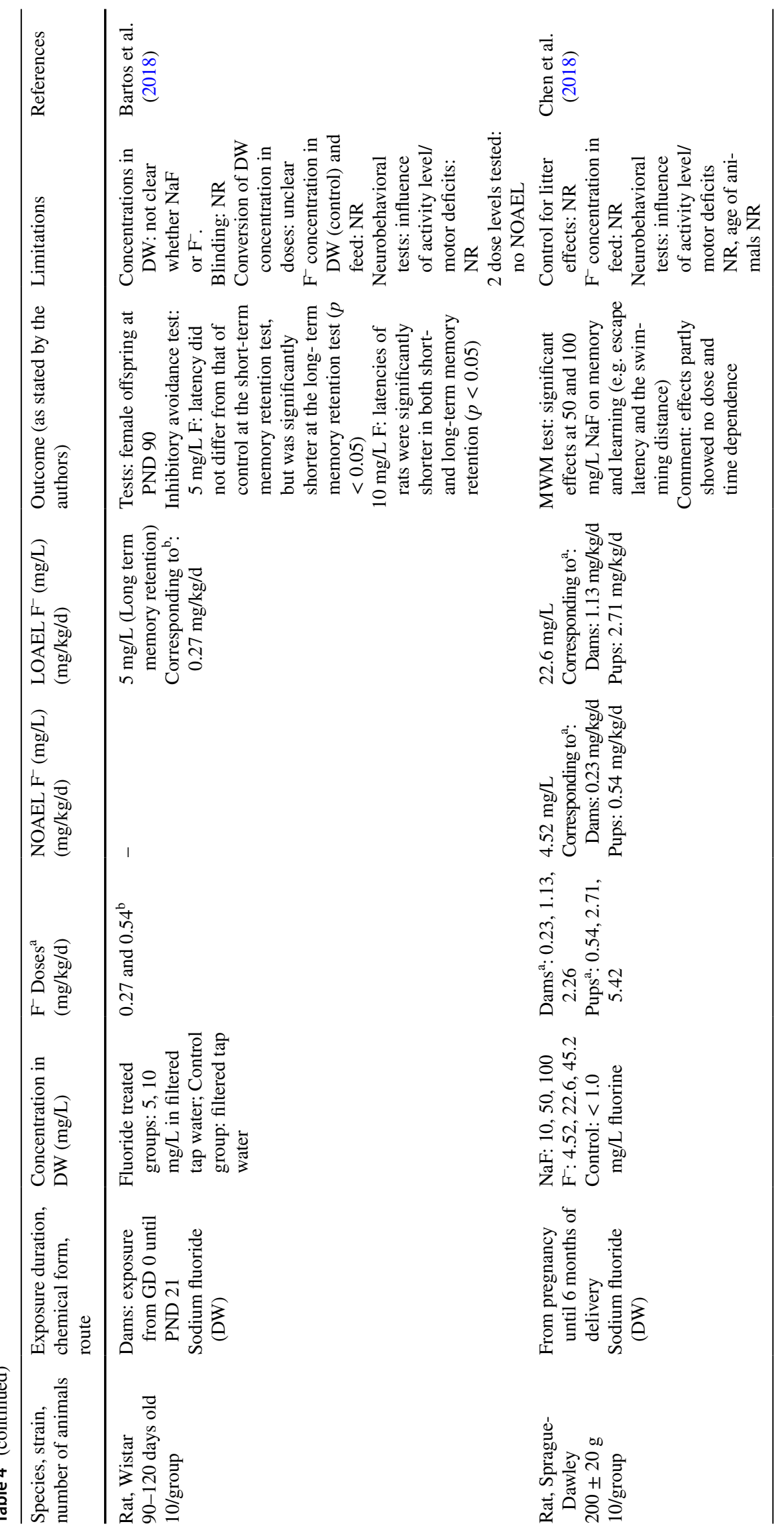




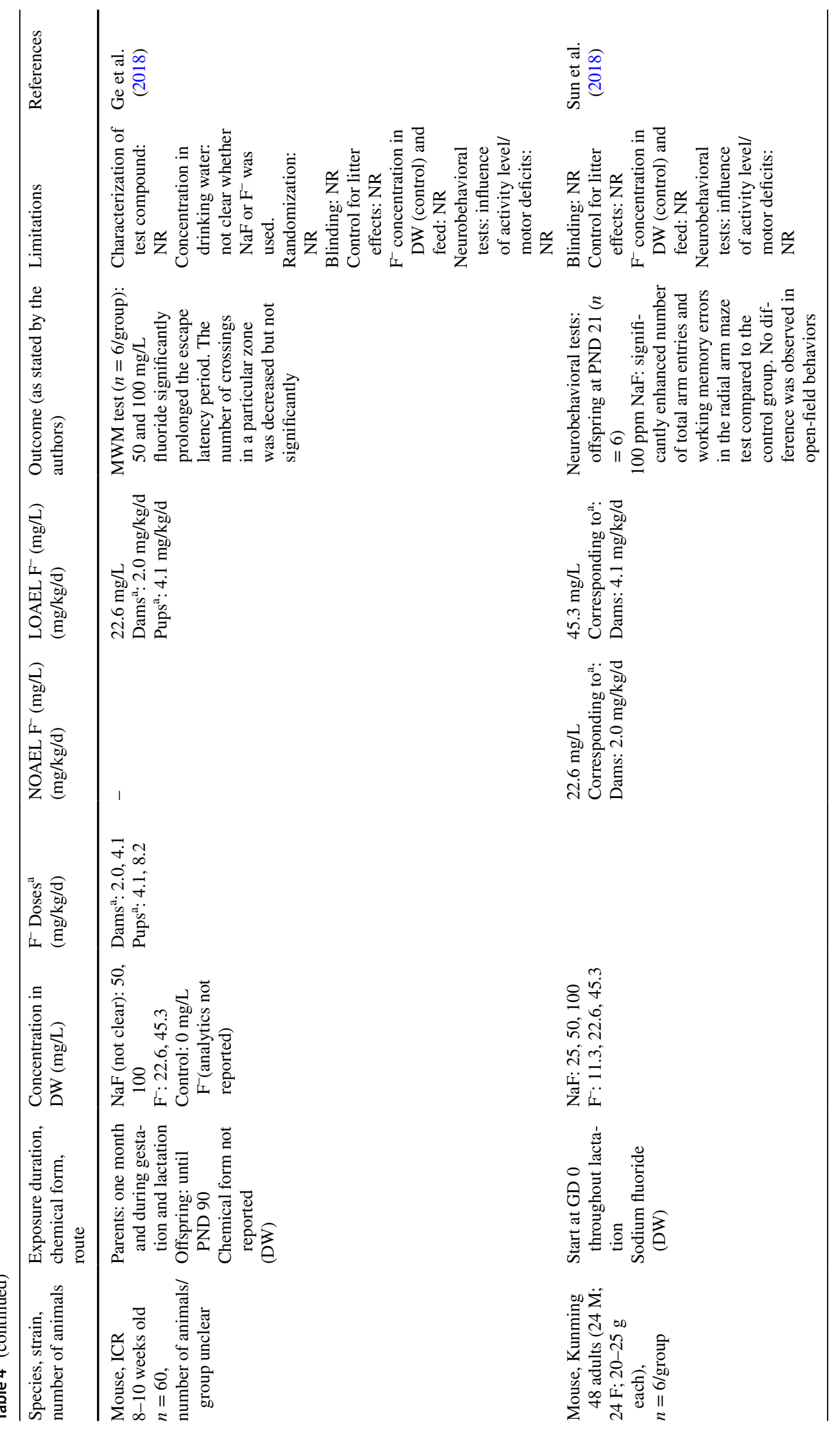




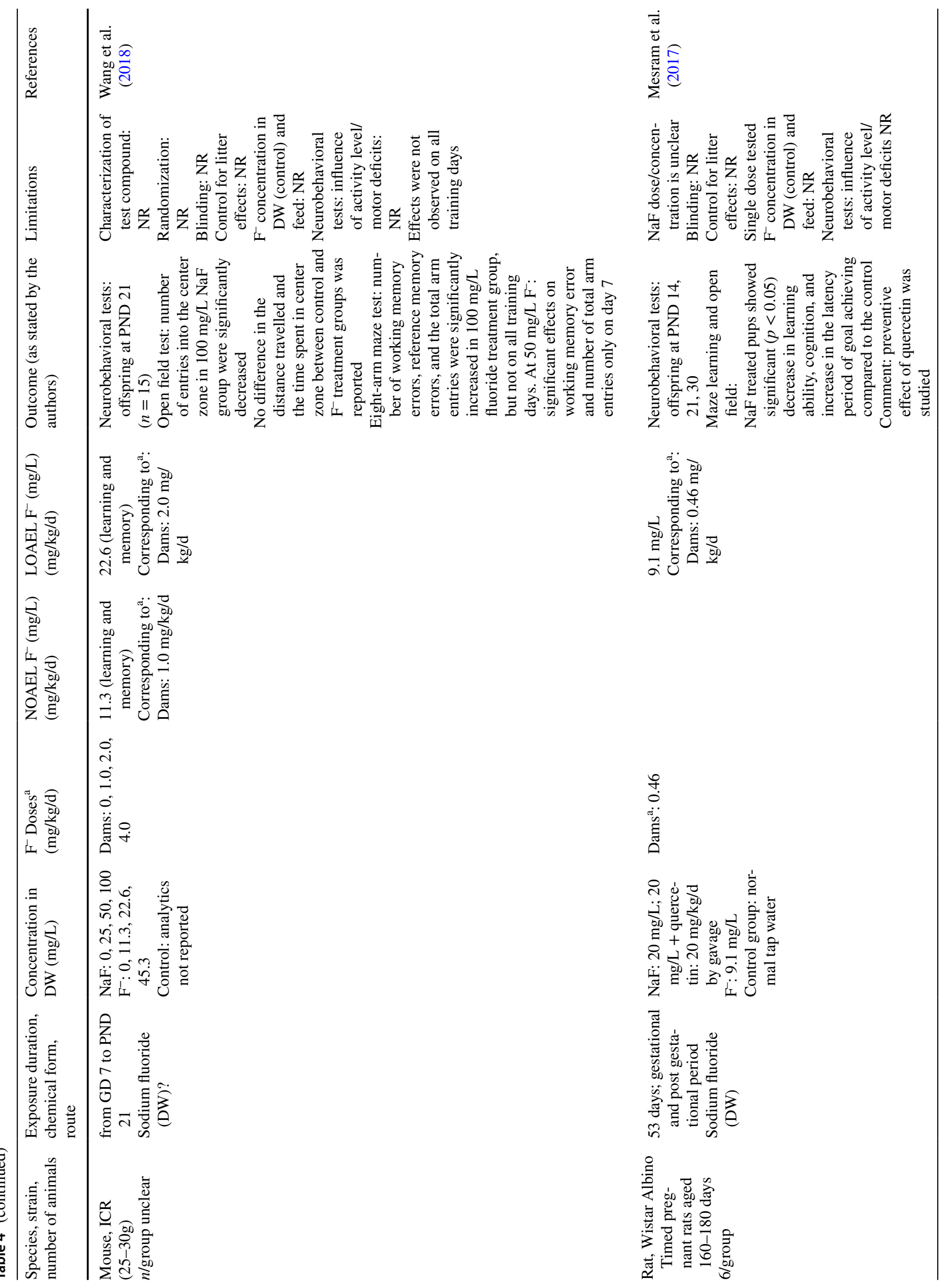




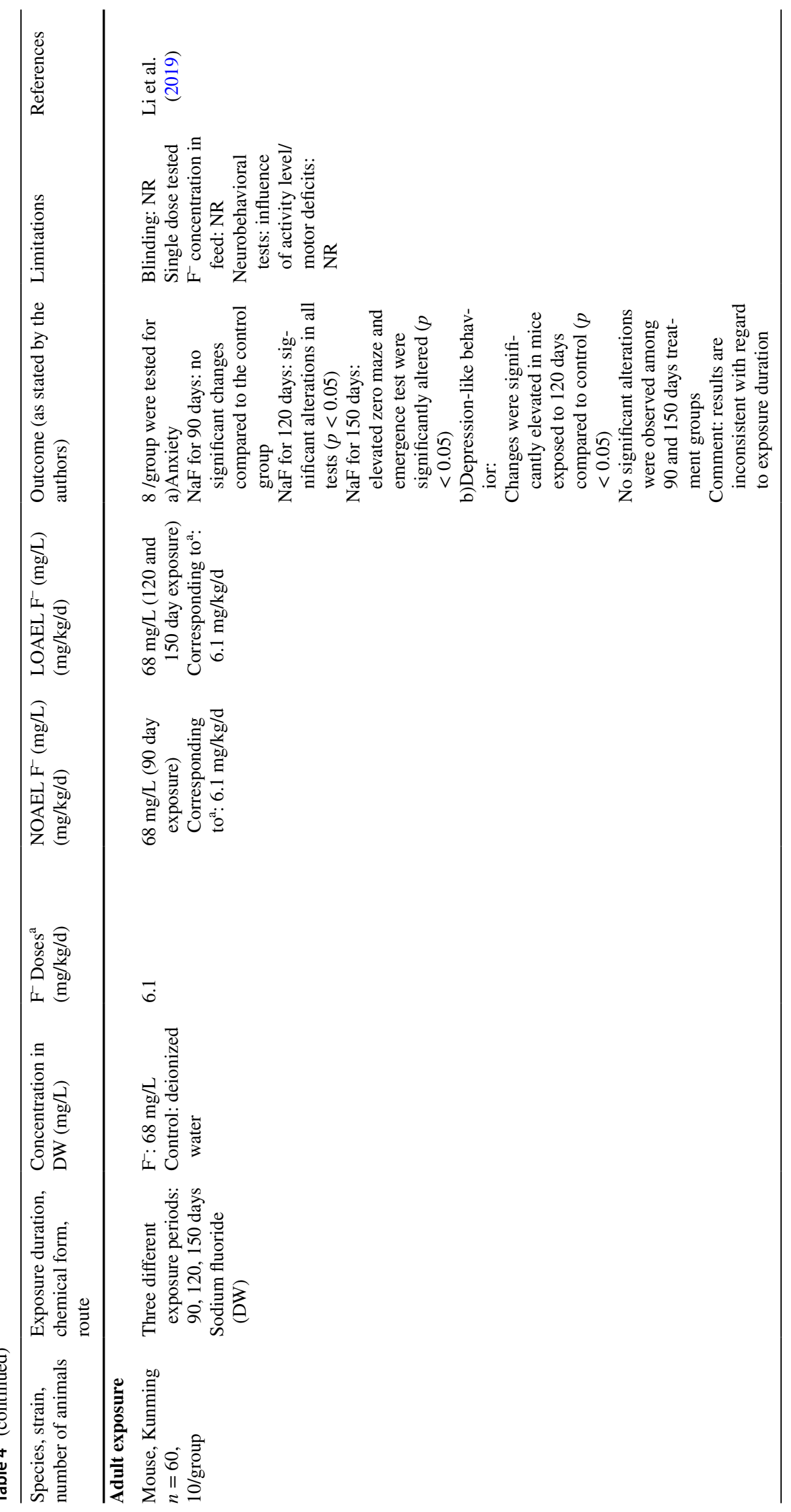




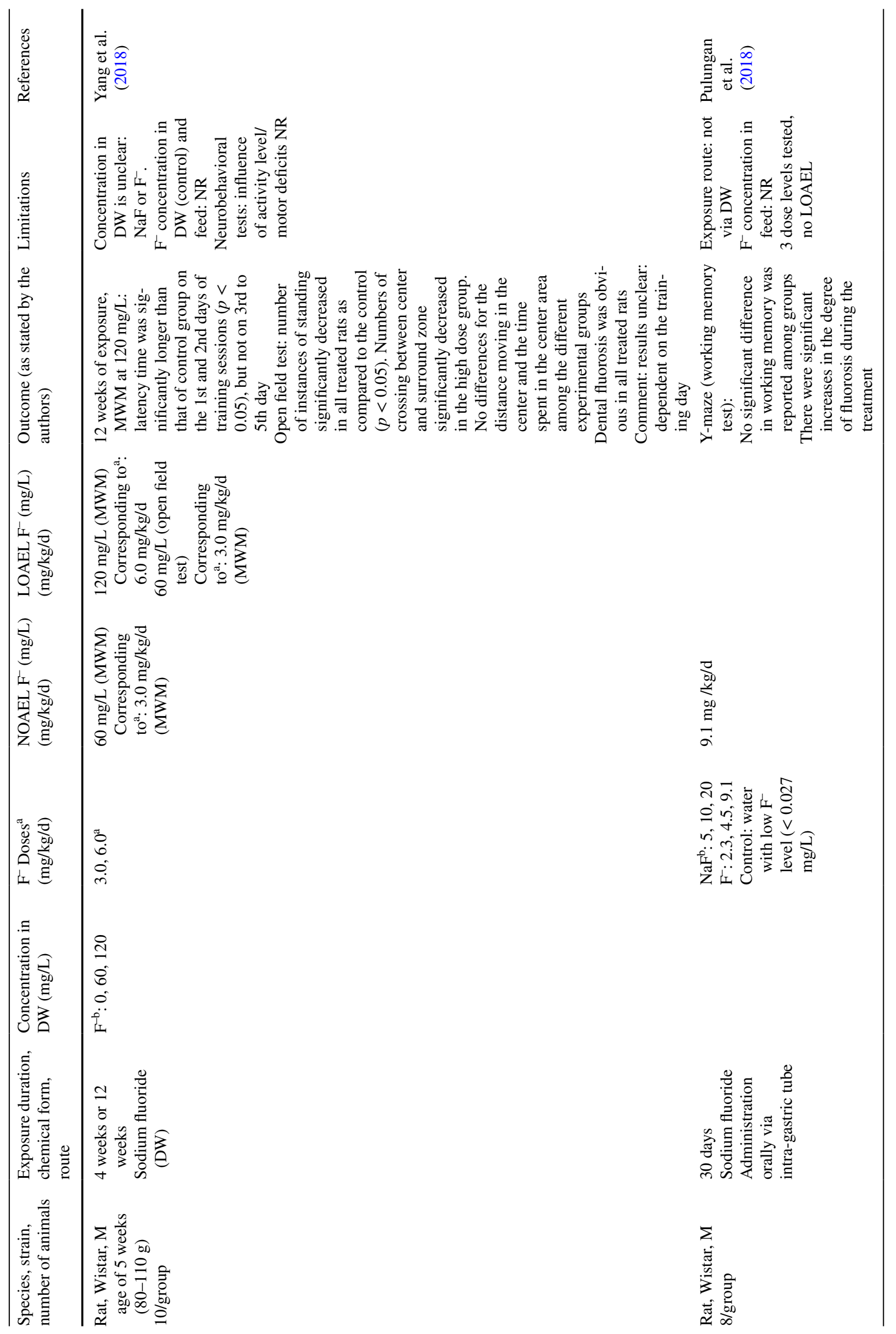




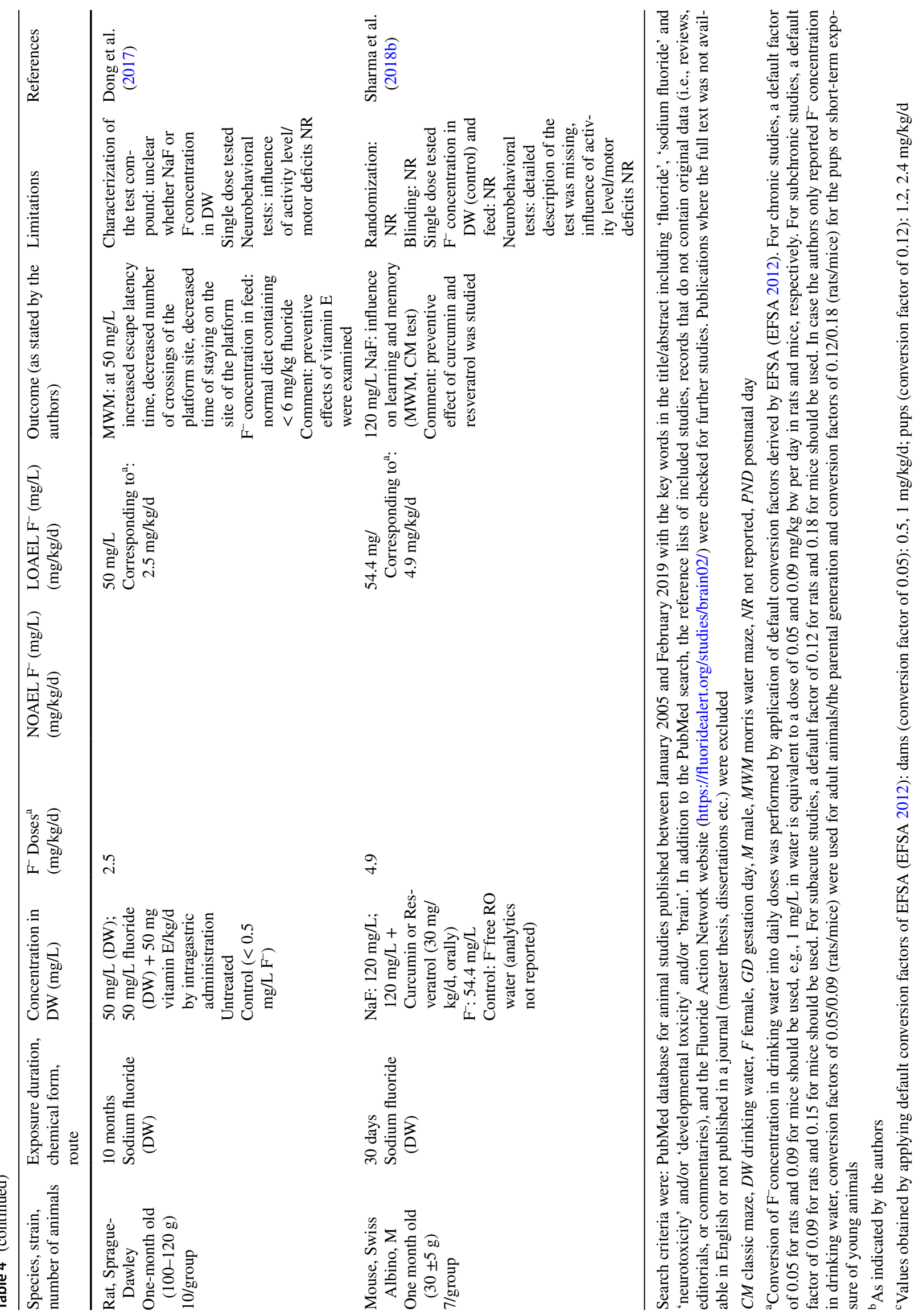


Furthermore, only a single high dose was investigated in some studies, which was identified as the LOAEL; therefore, no dose-response assessment was possible (Bouaziz et al. 2007; Zhao et al. 2015).

The group size in the studies was low, ranging from 5 to 10 animals whereas according to the respective standard guidelines, group sizes of more than 20 are required (e.g., OECD Guideline 426). The limitations of each single study are listed in Table 3. Overall, some of the studies could be used to gain initial mechanistic information, but were not appropriate to perform a dose-response assessment for developmental toxicity, or to derive a point of departure (POD) and an MoE. In the future, it will be important to clarify whether the observed lower LOAELs are valid by conducting standardized, quality-controlled studies. Furthermore, studies are also required that provide quantitative measures, such as effect size, POD, identification of a NOAEL, and a LOAEL dose, and parameters for a benchmark analysis [summarized by (NTP 2016)].

\section{Neurobehavioral studies and neurotoxicity}

Prior to the 2006 NRC review, few animal studies reported alterations in the behavior of rodents after treatment with fluoride (NRC 2006). According to NRC, the observed changes were judged to be not substantial in magnitude and it was stated that they could have been due to alterations in hormonal or peptide activity (NRC 2006). In recent years, numerous studies on the potential neurotoxicity of fluoride in experimental animals have been published. Detrimental effects on behavior in animal studies, including prioritizing assessment of learning and memory outcomes, have recently been reviewed by the National Toxicology Program (NTP 2016). Thirty percent of the studies identified were excluded from the systematic review due to concerns of bias, primarily because of at least three of the limitations already mentioned above. Of note, very few of the remaining studies assessed effects on learning and memory resulting from exposure to fluoride levels of approximately $0.7 \mathrm{mg} / \mathrm{L}$ - the recommended level for community water fluoridation in the USA (NTP 2016). Several studies suggested performance deficits in learning and memory tasks in rats when fluoride levels exceeded $100 \mathrm{mg} / \mathrm{L}$ in the drinking water (NTP 2016). A number of studies also reported such effects in rats at 2-50 mg/L fluoride [corresponding to $0.1-2.5 \mathrm{mg} / \mathrm{kg}$ b.w./day applying EFSA default conversion factors (EFSA 2012)]. However, many of these findings occurred in the presence of motor dysfunction or general toxicity, thus diminishing confidence in any conclusion regarding learning deficits (McPherson et al. 2018; NTP 2016). Overall, the systematic review by the NTP reported a low to moderate level of evidence for adverse effects on learning and memory in exposed animals with fluoride concentrations substantially higher than
$0.7 \mathrm{mg} / \mathrm{L}$ (NTP 2016). Evidence is strongest (moderate level of evidence) in exposed adult animals, and weakest (low level of evidence) in animals exposed during development (NTP 2016).

After the publication of the NTP report in 2016, several studies have been published, which investigated the impact of fluoride exposure on memory and learning in experimental animals (Table 4). Here, we differentiated between studies in animals exposed during pre- and postnatal development to those exposed as adolescents/young adults and reviewed the quality of these studies. Risk of bias among individual neurobehavioral studies was estimated following similar criteria as applied by the NTP (NTP 2016), taking also into account the relevant OECD guidelines (e.g., OECD test no. 426, developmental neurotoxicity study); (OECD 2007). We assumed that missing information (concerning, e.g., randomization, blinding, controlling for litter effects) was an indication that the respective aspect was not considered.

The following four key requirements were considered essential to achieve adequate and comparable study quality (as summarized by NTP 2016): randomization of treatment group, blinding during neurobehavioral outcome assessment, adequate characterization of the administered chemical, and controlling for litter effects (NTP 2016). According to NTP, randomization and blinding during outcome assessment are considered as particularly critical factors for risk of bias assessment (NTP 2016). There is empirical evidence that failure to apply these factors can bias results away from the null hypothesis toward larger effects (NTP 2016; OECD 2007). Lack of blinding at outcome assessment is attenuated if behavioral measurements are performed by an automated, computer-driven system (NTP 2016). In addition, concern for lack of blinding during allocation or the conduction of the study can be reduced if blinding was carried out at outcome assessment (NTP 2016). Adequate characterization of the test compound is essential to assess the purity and stability of the chemical exposure (NTP 2016). Independent confirmation of purity would be considered best practice, since impurities may be more toxic than the chemical of interest (NTP 2016). However, an analytical verification was not performed for any of the studies presented in Table 4 before the start of exposure. Finally, when littermates are evaluated in developmental studies, control for litter effects is essential (NTP 2016; OECD 2007). Studies should consider that pups from a single litter may respond more similarly to one another compared to pups from different litters (NTP 2016).

Eight studies published since 2017 investigated the effect of fluoride on learning and memory following exposure during development (Bartos et al. 2018; Chen et al. 2018a; Ge et al. 2018; McPherson et al. 2018; Mesram et al. 2017; Sun et al. 2018; Wang et al. 2018; Zhao et al. 2019); and five additional studies examined exposure during young 


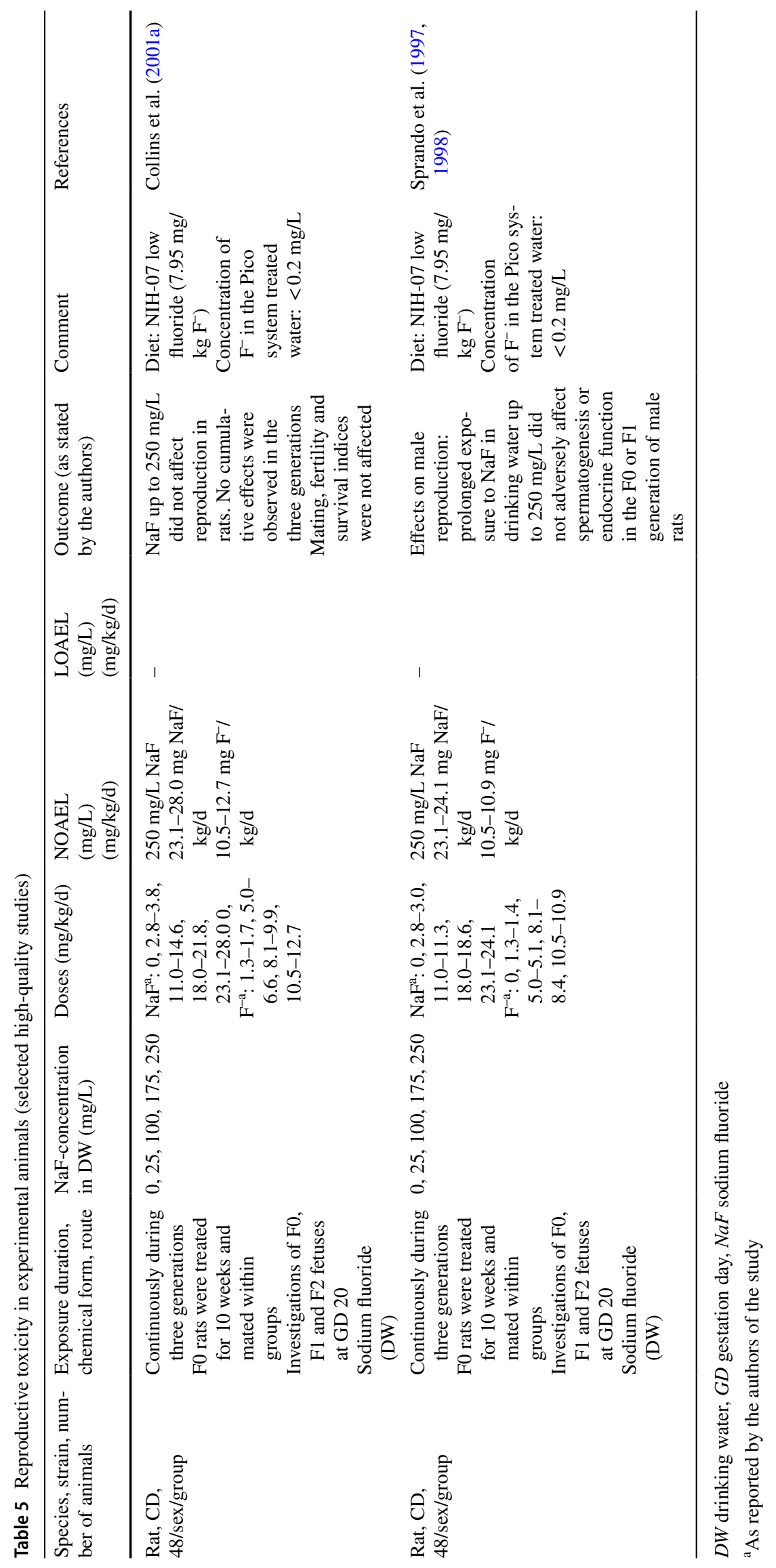


adulthood (Dong et al. 2017; Li et al. 2019; Pulungan et al. 2018; Sharma et al. 2018a; Yang et al. 2018). Only one study among them was conducted according to the generally accepted guidelines considering all of the aforementioned key requirements (McPherson et al. 2018). This recent study from the NTP laboratories was designed to address limitations identified in the NTP systematic review (McPherson et al. 2018; NTP 2016), and used exposure levels near the recommended level for community water fluoridation in the USA. For this purpose, equivalent human daily water intake of $1.74 \mathrm{mg}$ fluoride/day for an adult, or $0.63-1.23 \mathrm{mg} /$ day for children 1 to 14 years of age (EPA 2010) were approximated in rodents by using drinking water concentrations of 7-9 mg/L fluoride (NTP 2016). The highest dose of $20 \mathrm{mg} / \mathrm{L}$ fluoride was selected based upon the US EPA's maximum contaminant level of $4 \mathrm{mg} / \mathrm{L}$, based on the assumption that approximately fivefold higher doses are required for rats to achieve serum concentrations similar to those in humans (Dunipace et al. 1995; McPherson et al. 2018; NRC 2006). Pregnant Long-Evans hooded rats received a standard diet (20.5 mg/kg fluoride) or a low fluoride diet $(3.24 \mathrm{mg} / \mathrm{kg}$ fluoride) with drinking water containing 0,10 , or $20 \mathrm{mg} / \mathrm{L}$ fluoride from gestational day 6 throughout lactation. Male pups were exposed throughout adulthood and underwent neurobehavioral testing using different paradigms to assess learning and memory (NTP 2015). No exposure-related differences in motor, sensory, or learning and memory performance (running wheel, open-field activity, light/dark place preference, elevated plus maze, pre-pulse startle inhibition, passive avoidance, hot-plate latency, Morris water maze (MWM) acquisition, probe test, reversal learning, and Y-maze) were observed with either of the two exposure levels investigated (McPherson et al. 2018). Therefore, a LOAEL and a doseresponse assessment could not be established. In addition, there was no influence on thyroid hormone parameters (serum triiodothyronine (T3), thyroxine (T4), and thyroid stimulating hormone (TSH)). With the exception of mild inflammation in the prostate gland at $20 \mathrm{mg} / \mathrm{L}$ fluoride, no exposure-related pathology was observed in the heart, liver, kidney, testes, seminal vesicles, or epididymis (McPherson et al. 2018). Histological examination of the brain also revealed no evidence of neuronal death or glial activation in the hippocampus at the highest dose tested (McPherson et al. 2018). One further study which adequately considered the key requirements (Table 4) did not reveal any significant difference in working memory up to a fluoride dose of $9 \mathrm{mg} / \mathrm{kg}$ b.w./day (Pulungan et al. 2018). However, exposure was via an intragastric tube, and thus not representative of normal drinking water consumption. Three doses were investigated, none of which had an effect on memory and learning; therefore, a LOAEL and a dose-response relationship could not be established.
Some reports suggest that $\mathrm{NaF}$ has an effect on learning and memory. Six studies in rats (Bartos et al. 2018; Chen et al. 2018a; Dong et al. 2017; Mesram et al. 2017; Yang et al. 2018; Zhao et al. 2019) and five in mice (Ge et al. 2018; Li et al. 2019; Sharma et al. 2018a; Sun et al. 2018; Wang et al. 2018) reported such effects (mainly by investigating maze performance, e.g., MWM) with $20-120 \mathrm{mg} / \mathrm{L}$ $\mathrm{NaF}$ (9-54 mg/L fluoride) in drinking water corresponding to doses of approximately $0.46-6.1 \mathrm{mg} / \mathrm{kg}$ b.w./day. However, these studies had several limitations: two did not give adequate information with regard to the four key requirements (Ge et al. 2018; Wang et al. 2018). The overall reporting of data was insufficient and indicative of a high risk of bias. The remaining studies also revealed one to three of the key limitations (Table 4), e.g., lack of reporting of blinding (Bartos et al. 2018; Li et al. 2019; Mesram et al. 2017; Sharma et al. 2018a; Sun et al. 2018) or randomization (Sharma et al. 2018a), lack of controlling for litter effects (Chen et al. 2018a; Mesram et al. 2017; Sun et al. 2018; Zhao et al. 2019), or the lack of a clear characterization of the test compound, i.e., whether concentrations or dose levels refer to fluoride or sodium fluoride (Bartos et al. 2018; Dong et al. 2017; Mesram et al. 2017; Yang et al. 2018). Furthermore, only a single dose was investigated in several studies (Dong et al. 2017; Li et al. 2019; Mesram et al. 2017; Sharma et al. 2018a), which was identified as the LOAEL. In most of the studies, only single parameters were explored, which also is considered to be a study limitation. The group size in almost all studies was low, ranging from five to ten animals and did not meet the requirements of the relevant guidelines. Nevertheless, some of the findings, e.g., by Zhao et al. (2019), were quite consistent concerning neurobehavioral and neuropathological outcomes, thus requiring further investigations. They reported that $22.6 \mathrm{mg} / \mathrm{L}$ fluoride in drinking water (corresponding to approximately $2.7 \mathrm{mg} / \mathrm{kg}$ b.w./day fluoride, Table 4) caused learning and memory impairments (MWM test) in pups, which were accompanied by mitochondrial morphological alterations in the hippocampus manifested as fission suppression and fusion acceleration, along with defective autophagy, excessive apoptosis, and neuronal loss (Zhao et al. 2019).

Fluoride exposure originates from multiple sources (NTP 2016). However, information on alternative sources, such as food or water supply, was lacking in the majority of the aforementioned studies. When reported, fluoride levels in control water ranged from 0.03 to less than $1.0 \mathrm{mg} / \mathrm{L}$ and in rodent feed from $3.2-20.5 \mathrm{mg} / \mathrm{kg}$. Furthermore, the majority of the studies investigated high doses of fluoride, which are not relevant for human exposure. Most studies examining the effects of fluoride exposure on learning and memory have only investigated avoidance conditioning or maze performance, both of which can be influenced by general activity level or motor deficits, thus limiting the ability to accurately 
evaluate a specific effect of fluoride on these parameters (NTP 2016).

The NTP review focused on selected behavioral measures, and did not include studies examining the effect of fluoride exposure on brain-related cellular, morphometric, or histological end points, or its influence on thyroid function, which may alter specific neurobehavioral measures (NTP 2016). These end points, last reviewed by the NRC (NRC 2006), provided evidence that fluoride interferes with brain and other physiological functions by both direct and indirect means (NRC 2006). However, the observed changes may be subtle or seen only under certain physiological or environmental conditions (NRC 2006). Potential mechanisms described by the NRC included reduced brain content of lipids and phospholipids, and enzymes that metabolize them, such as phosphohydrolases and phospholipase $\mathrm{D}$, as well as the inhibition of cholinesterase activity (including acetylcholinesterase) and a reduction of acetylcholine (NRC 2006).

Since publication of the NRC report in 2006, numerous brain-related histological, chemical, and molecular studies have been conducted, and approximately 130 studies were identified from 2007 to 2019. A complete analysis of these studies was not within the scope of the present review, but importantly, some of the more recent studies that focused on neurobehavioral effects also addressed the histology/biochemistry underlying putative effects of fluoride. The results of these more recent studies are quite diverse, which may be due to different experimental setups (e.g., test concentrations, species/strain and age of the animals, exposure duration), but also due to several limitations (see Table 4). Most of the newer studies appear to support the conclusions of the NRC report (NRC 2006); however, some contradict findings of previous studies showing that fluoride at lower concentrations could interfere with brain functions. For example, a histological examination of the brain revealed no evidence of neuronal death or glial activation in the hippocampus upon exposure to $20 \mathrm{mg} / \mathrm{L}$ fluoride in drinking water (McPherson et al. 2018). There was also no significant difference in the number of pyramidal neurons in the medial prefrontal cortex cells after administration of 5,10, and $20 \mathrm{mg} / \mathrm{kg}$ b.w./day of oral NaF solution (Pulungan et al. 2018). Other studies observed neuronal death or dysfunction in the rat hippocampus at concentrations of $10-120 \mathrm{mg} / \mathrm{L} \mathrm{NaF}$ in drinking water (Basha et al. 2011; Chen et al. 2018a; Sharma et al. 2018a; Shashi and Kumar 2016; Teng et al. 2018; Wang et al. 2018; Yan et al. 2016; Zhao et al. 2019), an influence on neurotransmitter signaling (Dong et al. 2017; Sun et al. 2018), and induction of oxidative stress in the brain (Bartos et al. 2018; Dong et al. 2017). Further studies also reported stimulation of microglia following fluoride exposure (Shuhua et al. 2012; Yan et al. 2013, 2016; Yang et al. 2018). Factors accounting for the differences in the neuropathological findings between studies include differences in fluoride levels in food and the water source, as well as potential processing artifacts for neuronal death, e.g., the presence of contracted, intensely stained neurons (so-called 'dark neurons') which can be produced by postmortem manipulation or trauma in brain tissue (Jortner 2006; McPherson et al. 2018).

\section{Reproductive toxicity}

A large number of studies evaluated the reproductive tract structure or function in animal models, primarily for the purpose of hazard identification using high doses of fluoride to reveal potentially sensitive reproductive tract targets and pathways (NRC 2006). The NRC, in its 2006 report, summarized some representative examples to provide an overview of the conclusions drawn from these studies (NRC 2006): (1) cessation of spermatogenesis and alterations in the epididymis and vas deferens were observed in rabbits administered $\mathrm{NaF}$ at $10 \mathrm{mg} / \mathrm{kg}$ b.w./day for 29 months (Susheela and Kumar 1991); (2) effects on Leydig cells and decreased serum testosterone were observed in rats exposed to $\mathrm{NaF}$ at $10 \mathrm{mg} / \mathrm{kg}$ b.w./day for 50 days (Narayana and Chinoy 1994); and (3) decreased activity of the steroidogenic enzymes (3ß-hydroxysteroid dehydrogenase [HSD] and 17 $\beta$-HSD) was found in the ovary and uterus of mice treated with $\mathrm{NaF}$ at $10 \mathrm{mg} / \mathrm{kg}$ b.w./day for 30 days (Chinoy and Patel 2001). In general, these studies show adverse effects of fluoride on the reproductive tract at concentrations sufficiently high to also induce other signs of toxicity.

A comprehensive multigenerational study of the effects of fluoride on reproduction has been conducted in rats using standard guidelines and the adequate numbers of animals (Collins et al. 2001a) (Table 5). Rats were administered drinking water with $\mathrm{NaF}$ at $0,25,100,175$, and $250 \mathrm{mg} / \mathrm{L}$ for three generations. No compound-related effects were found on mating or fertility, gestation or lactation, F1 survival, development, or organ weight. There were also no alterations to teeth, except for mild whitening observed in rats exposed to fluoride at $100 \mathrm{mg} / \mathrm{L}$ or greater. This wellconducted study concluded that $\mathrm{NaF}$ at concentrations of up to $250 \mathrm{mg} / \mathrm{L}$ in drinking water, which corresponds to a fluoride dose of $10.5-12.7 \mathrm{mg} / \mathrm{kg} / \mathrm{day}$, did not alter reproduction in rats (Collins et al. 2001a; NRC 2006). Since 2006, there have been numerous studies published investigating the effects of fluoride exposure during adolescence/adulthood on various reproductive parameters; however, a detailed analysis of these studies was beyond the scope of the present review. 


\section{Epidemiological studies: does fluoride act as a human developmental neurotoxicant?}

In recent years, reviews have been published that cite epidemiological studies that are supportive of the view that 'normal fluoride exposure' (via drinking water, dietary intake, toothpaste etc.) is harmful to humans; fluoride has also been categorized as a developmental neurotoxicant (Duan et al. 2018; Grandjean and Landrigan 2014; Nakamoto and Rawls 2018). A widely recognized and discussed example is the review by Grandjean and Landrigan published in Lancet Neurology (Grandjean and Landrigan 2014).

In this publication, the authors cited one of their previous studies, a meta-analysis from 2012 of 27 cross-sectional studies investigating children exposed to fluoride in drinking water (Choi et al. 2012). There, a decreased IQ was observed in 'fluoride exposed' compared to 'reference populations'. However, Choi et al. (Choi et al. 2012) also discussed limitations of their findings, e.g., that critical confounders were not considered and age adjustment of cognitive test scores were not reported in most studies included in the meta-analysis. Nevertheless, in the Lancet Neurology review (Grandjean and Landrigan 2014), the authors concluded that fluoride is a human developmental neurotoxicant, although no novel data and arguments were presented. Moreover, it was stated that 'confounding from other substances seems unlikely in most of these studies' (Grandjean and Landrigan 2014) without supporting this statement with data. Besides this questionable reinterpretation, further limitations of the meta-analysis have already been discussed in detail by other authors (Feldman 2014; Gelinas and Allukian 2014; Sabour and Ghorbani 2013; Sutton et al. 2015), e.g., the use of non-validated IQ tests (Feldman 2014), exposure of the children to a relatively highly polluted environment, the subsequent risk of possible confounding substances (Feldman 2014; Gelinas and Allukian 2014), and an overall low quality of the metaanalysis (Sutton et al. 2015). Moreover, in the time period after the introduction of fluoridation of drinking water, IQs in general have increased (Feldman 2014). This may be due to secondary factors, such as improved education.

\section{Epidemiological studies since 2012}

To reach a better understanding of potential associations between fluoride exposure and human intelligence, we conducted a literature search of epidemiological studies published between January 2012 and August 2019. A compilation of the 23 epidemiological studies identified is given in Table 6. Twenty studies were conducted with a crosssectional design, one with a longitudinal (Bashash et al. 2017), and two with a prospective design (Broadbent et al. 2015; Green et al. 2019). The main analyzed endpoint was
IQ in 22 of 23 studies, with one study examining an association between fluoride exposure and school performance (Mustafa et al. 2018). Study locations were: 13 in India, 4 in China, 2 in Iran, 1 in Sudan, 1 in Mexico, 1 in Canada, and 1 in New Zealand. All studies investigated human intelligence in children and adolescents, between the ages of 3 and 14 years. One study additionally considered intelligence in adults (Broadbent et al. 2015). Twenty-one of the 23 studies concluded that higher fluoride exposure was associated with lower intelligence. In contrast, two studies did not observe any association (Broadbent et al. 2015; Sharma et al. 2018c).

\section{Limitations of epidemiological studies}

So far, almost all studies investigating the effect of fluoride intake on intelligence were performed in relatively poor, rural communities, e.g., in China, Iran, and Mongolia, where drinking water may contain comparatively high levels of fluoride ('exposed population'), whereas the 'reference populations' often had access to water that was fluoridated at the recommended level (critically discussed by (Feldman 2014; Gelinas and Allukian 2014)). This constellation may lead to a confounding effect; rural regions with unusually high or unusually low fluoride in drinking water may be associated with a less developed health-care system, as well as lower educational and socioeconomic status. Furthermore, in these regions the overall nutritional status and the intake of essential nutrients may be lower and the exposure to environmental contaminants such as lead, cadmium, mercury, or manganese may be higher-factors that are also discussed to have a potential impact on intelligence (e.g., Carrington et al. 2019; Bouchard et al. 2011; Hibbeln et al. 2007). Conversely, relatively rich communities with access to better education and/or higher socioeconomic status may more likely invest in having high-quality drinking water, e.g., to avoid fluoride concentrations above $1.5 \mathrm{mg} / \mathrm{L}$ to decrease the risk of dental fluorosis, and can afford reduction of high fluoride concentrations through filtration. In addition, particularly low fluoride concentrations in drinking water can be rectified by fluoridation at adequate levels. However, both measures require a relatively advanced public health-care system.

Notably, only two studies published since 2012 investigated the effect of fluoride exposure in drinking water resulting from community water fluoridation (CWF) (Broadbent et al. 2015; Green et al. 2019), i.e., in areas where water is fluoridated with a precise dose of fluoride as a public health prevention measure. In contrast, most of the studies (21 of 23 studies) investigated the effect of fluoride exposure in drinking water resulting from endemically occurring fluoride. In these studies, fluoride is naturally present at varying concentrations, with minimum levels of $0.08 \mathrm{mg} / \mathrm{L}$ (Mustafa et al. 2018) and maximum levels of $18.08 \mathrm{mg} / \mathrm{L}$ (Mondal 
et al. 2016). To maintain electroneutrality, (drinking) water with higher concentrations of endemically occurring fluoride must contain higher concentrations of positive ions to balance out the fluoride. This may affect the $\mathrm{pH}$ of the water or result in greater contamination by electropositive water contaminants, for example aluminum, zinc, arsenic, lead, mercury, and other metals and metalloids. Thus, in studies of naturally occurring fluoride, it is important to control for these contaminants. On the other hand, in studies of community water fluoridation, the negative fluoride ions are balanced out in the water treatment process; therefore, other substances are unlikely to be a source of confounding.

As a measure of exposure, some studies did not use individual level exposure, i.e., by individual drinking water samples, urinary fluoride samples, or dental fluorosis measurements. Frequently, the fluoride content in drinking water in the residential area of the study participants was used as a proxy which is considered to be a notable study limitation. Furthermore, it should be noted that many studies have used creatinine-adjusted urinary fluoride concentrations to account for urinary dilution which may cause an additional bias. Findings of a systematic review and meta-analysis suggest that kidney function may be associated with IQ, and children with chronic kidney disease may have below average neurocognitive and academic outcomes (Chen et al. 2018 b). An additional limitation is the often-used crosssectional study design, which is appropriate when an acute event (e.g., asthma) and the possible source of exposure (e.g., airborne pollen) occur very close to each other, since both parameters are measured simultaneously. However, cross-sectional and ecological studies do not allow the establishment of causal relationships and are not appropriate to ultimately evaluate the effect of a chronic fluoride exposure on a parameter like human intelligence, but serve to derive hypotheses.

In contrast, prospective studies in which cohorts are followed over a period of time, and data relating to predetermined exposures and outcomes that are collected over time, are considered appropriate for inferring causality (Sutton et al. 2015).

Another aspect is the control of confounding factors, which are known to influence intelligence, by using an optimal study design, i.e., statistical adjustment. Of the 23 studies that were published since 2012, only 11 performed a statistical adjustment for potential confounding factors, and in most of these studies the included confounders were incomplete. Twelve of 23 studies aimed to consider the influence of potential confounding factors by their study design, e.g., by comparing populations with 'similar characteristics', did not consider the influence of confounding factors at all, or did not comment on this fact (Table 6).
Assessment of prospective epidemiological studies

In summary, most epidemiological studies performed in rural areas reported an association of high fluoride exposure with lower intelligence. Most of these studies are of low quality (e.g., insufficient control of confounding factors, no individual level exposure assessment) and inadequately designed to prove or disprove hypotheses (crosssectional). The results of the two available studies with a suitable study design (prospective cohort studies) conducted in non-endemic CWF areas that also appropriately considered confounding factors (even though there are still some limitations, see below) are conflicting. First of all, it has to be noted that the two studies address different questions. One study investigated the influence of fluoride exposure on the development of intelligence at various time points, ranging from infancy to adulthood (Broadbent et al. 2015). The other study examined the influence of fluoride exposure during pregnancy on the intelligence of children only once at an age between 3 and 4 years (Green et al. 2019), i.e., at an age range where performance in intelligence tests is improving quite rapidly.

The first of the two prospective cohort studies was performed with a general population sample of 1.037 children born in Dunedin, New Zealand, between 1 April 1972 and 30 March 1973 (Broadbent et al. 2015). The participants were followed for 38 years and their fluoride intake via drinking water (residence in a CWF area versus non-CWF area; $0.7-1.0 \mathrm{mg}$ fluoride/L vs. $0.0-0.3 \mathrm{mg}$ fluoride/L), fluoride dentifrice, and/or $0.5 \mathrm{mg}$ fluoride tablets in early life (prior to age 5 years) was deduced. IQ was assessed repeatedly between ages 7 and 13 years and at age 38 years. It was reported that no statistically significant differences in IQ due to fluoride exposure were observed also following adjustment for potential confounding variables, including sex, socioeconomic status, breastfeeding, and birth weight (as well as educational attainment for adult IQ outcomes).

The second prospective cohort study conducted in Canada was performed with children born between 2008 and 2012 (Green et al. 2019). Forty-one percent lived in communities supplied with fluoridated municipal water. Samples were taken from 601 mother-child pairs and the children were between ages 3 and 4 years at intelligence testing. Maternal urinary fluoride (MUF), adjusted for specific gravity and averaged across three trimesters, was measured for 512 pregnant women, self-reported maternal daily fluoride intake from water and beverage consumption was available for 400 pregnant women. The authors concluded that maternal exposure to higher levels of fluoride during pregnancy was associated with lower full-scale IQ scores in children (Green et al. 2019). This effect was significant, albeit rather small and restricted to boys. Thus, an increase of $1 \mathrm{mg} / \mathrm{L}$ of MUF was significantly associated with a $4.49(95 \%$ CI -8.38 to 


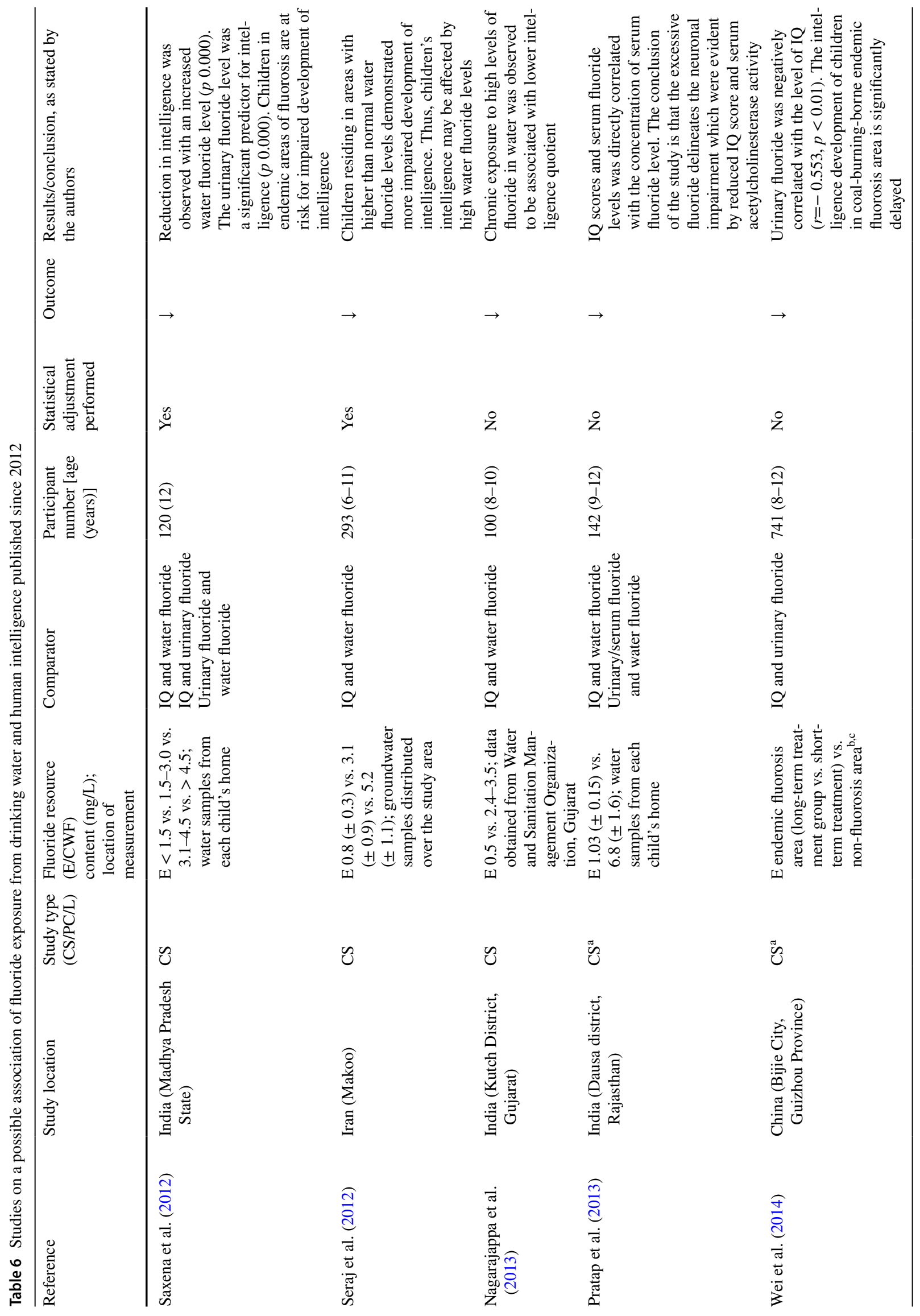




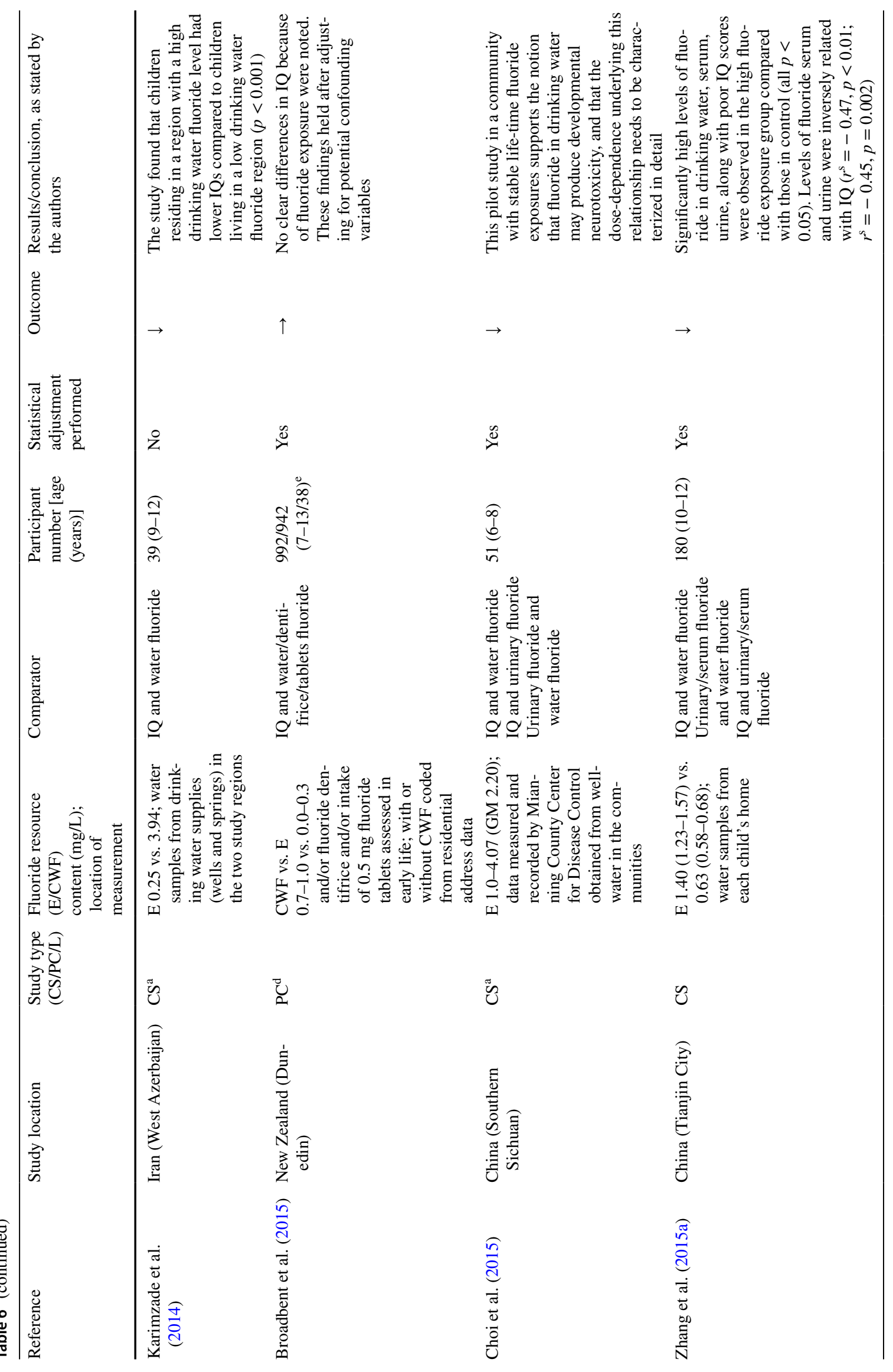




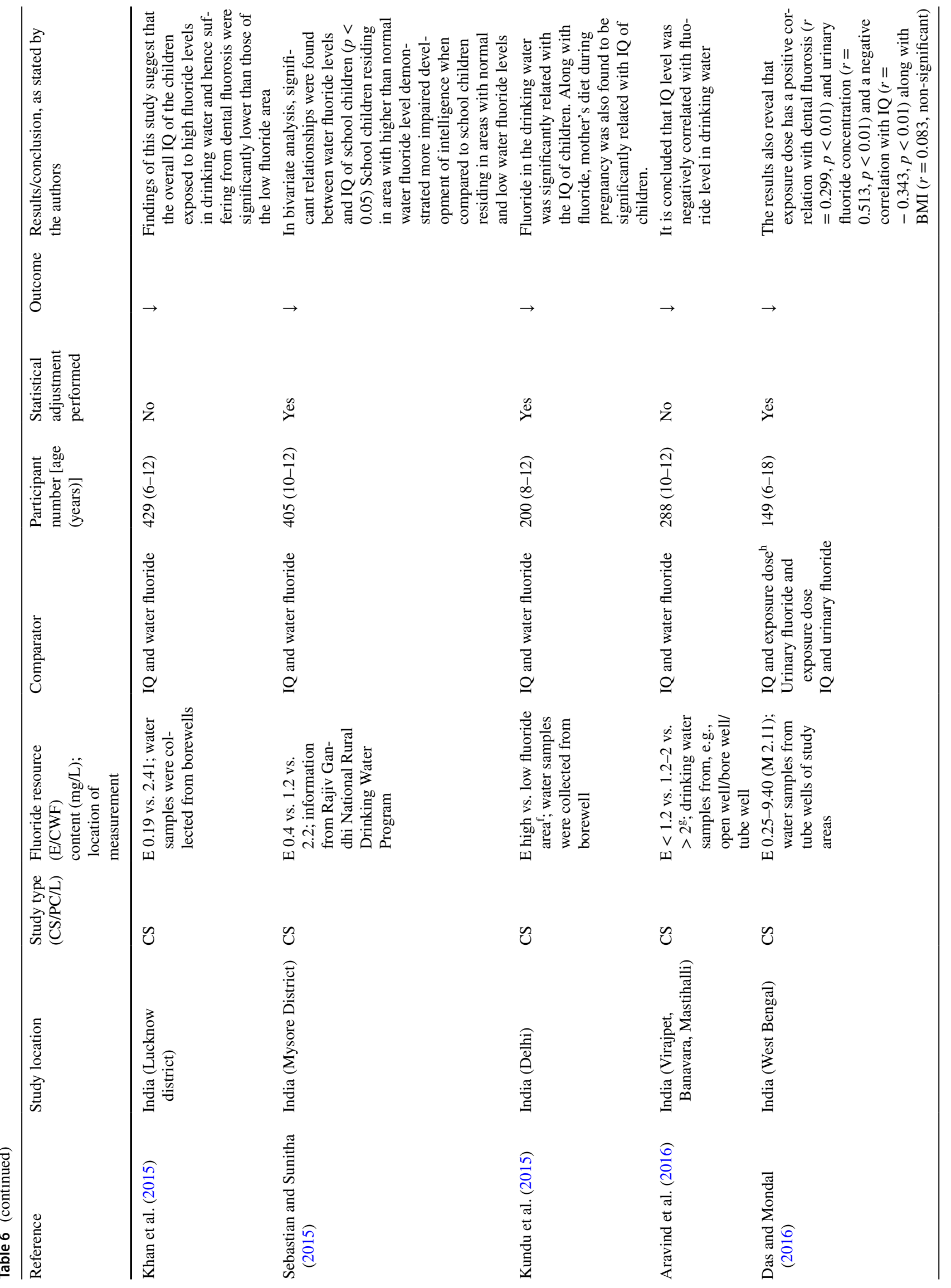




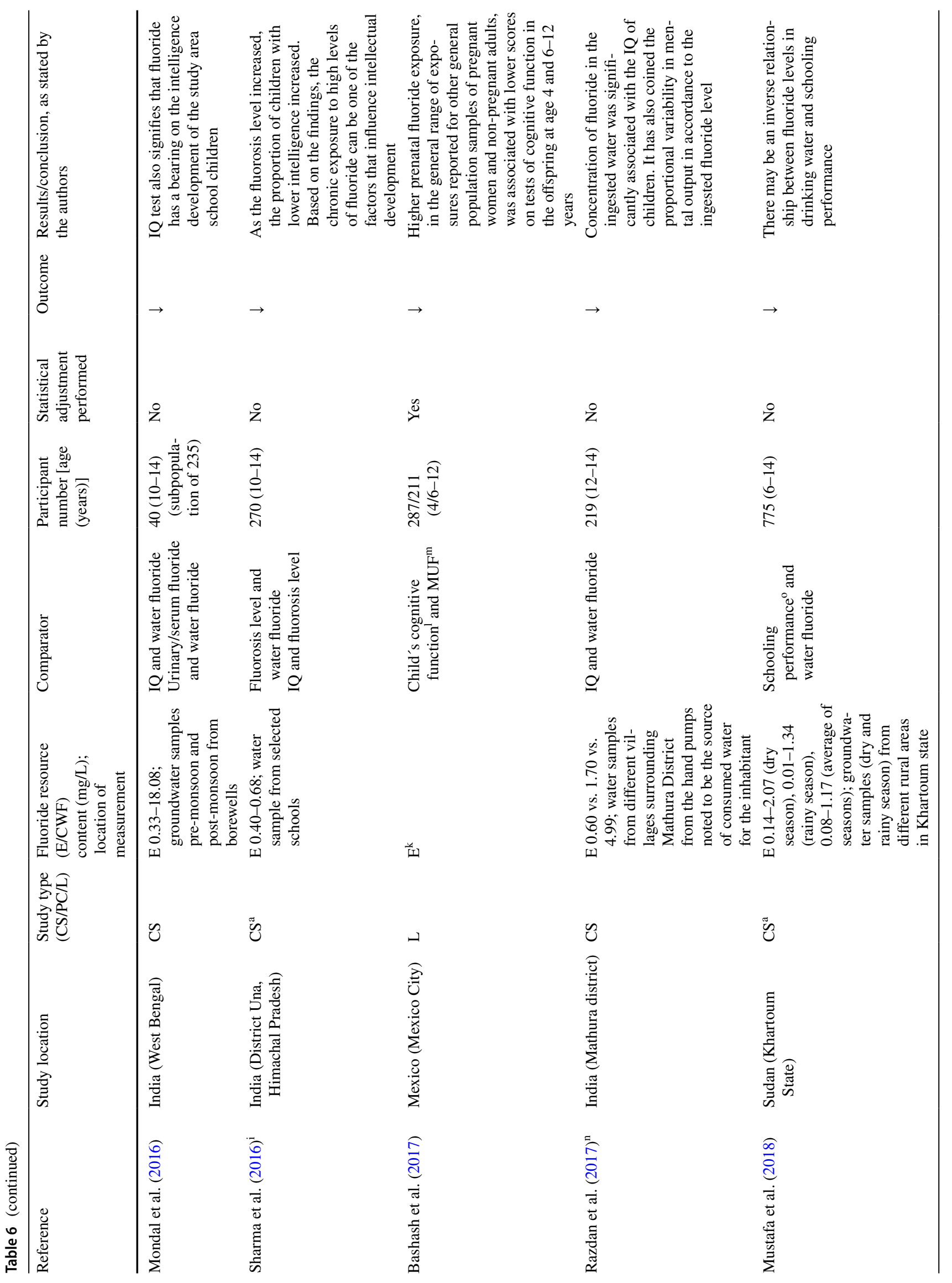




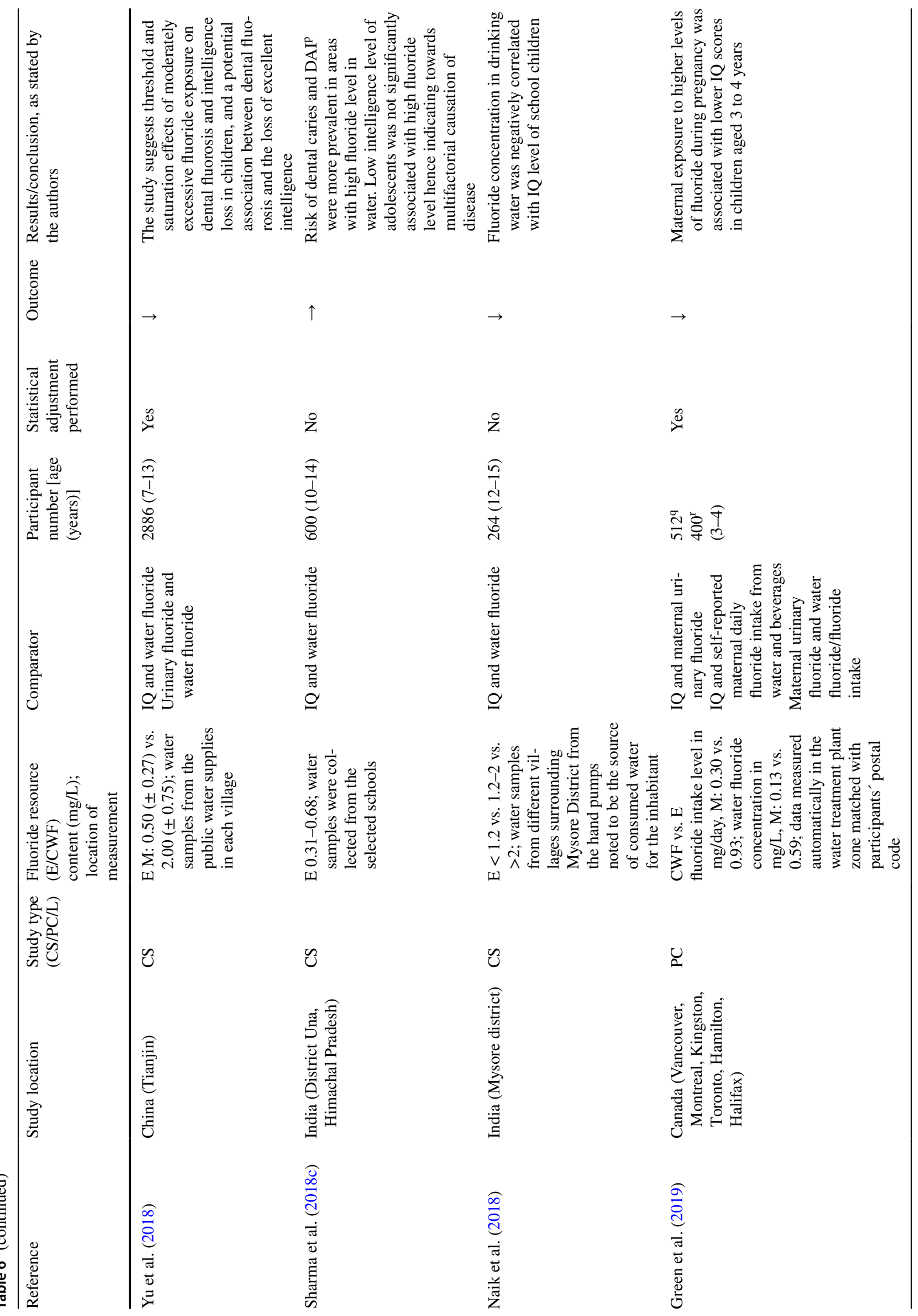




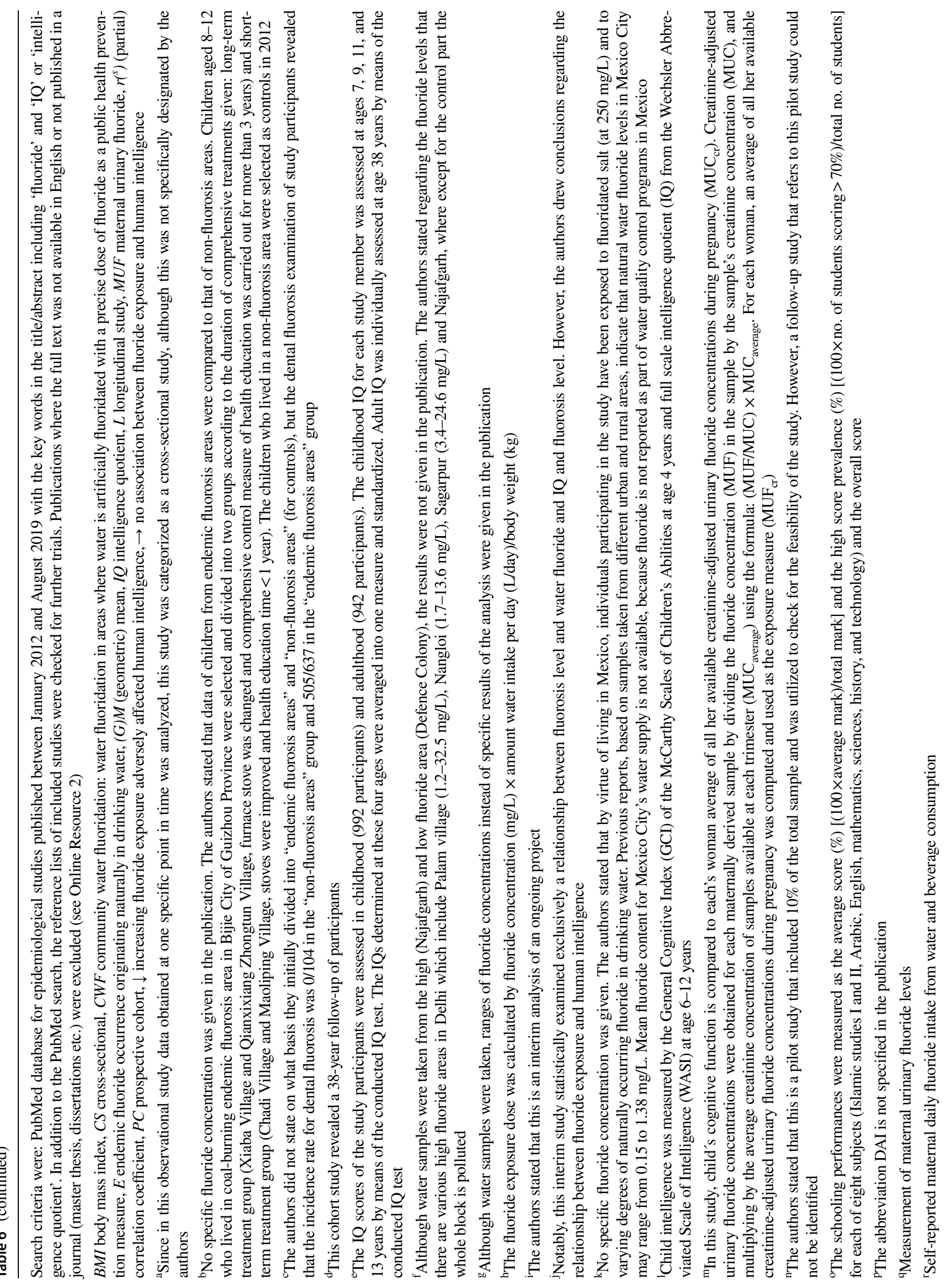


Table 7 Comparison of prospective epidemiological studies

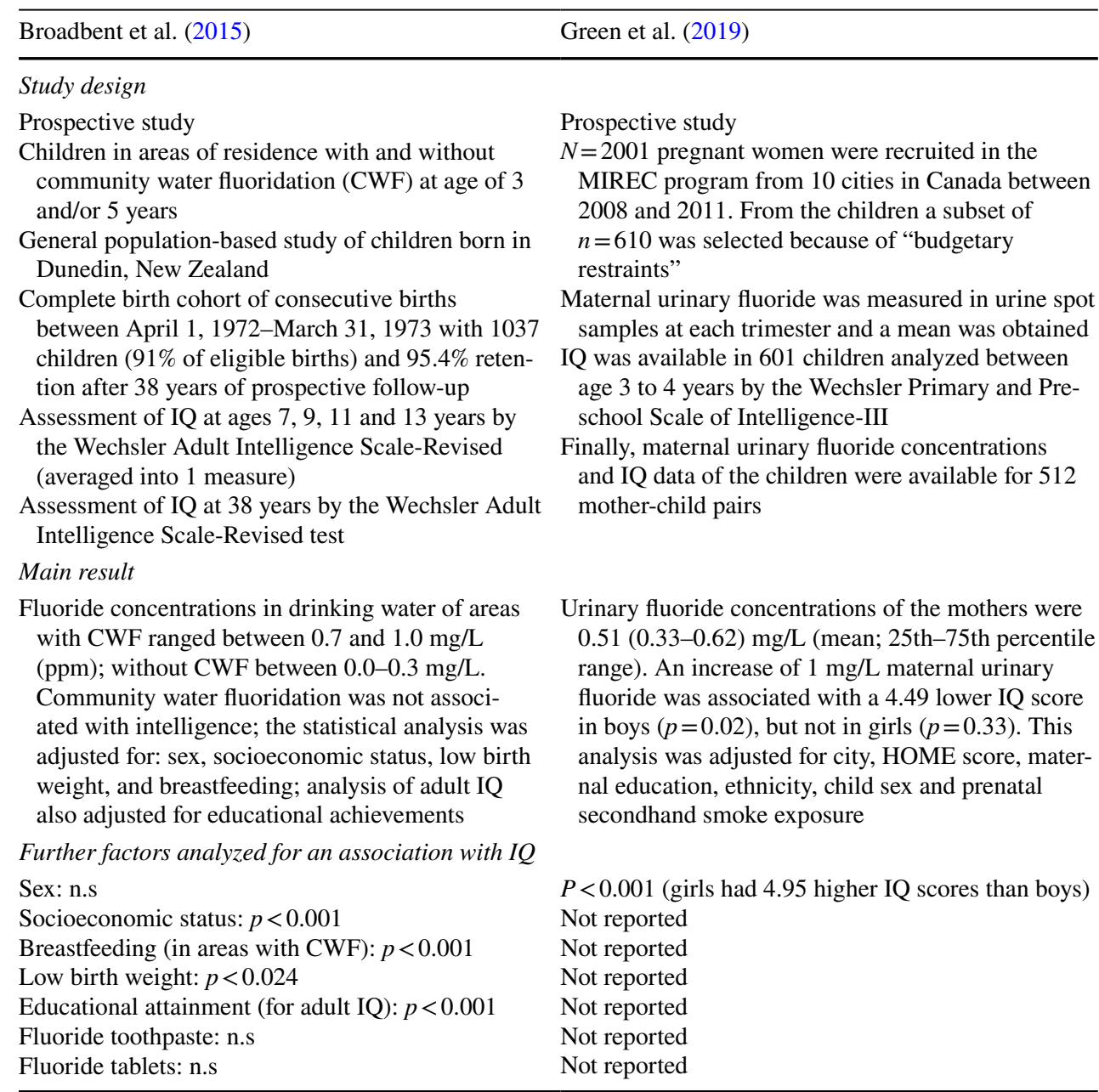

n.s. not significant
- 0.60) lower FSIQ score in boys, whereas girls showed a slight but not significant increase in IQ scores $(B=2.40 ; 95 \%$ $\mathrm{CI}-2.53$ to 7.33 ). A 1-mg higher daily intake of fluoride among pregnant women was significantly associated with a 3.66 lower IQ score (95\% CI - 7.16 to - 0.14 ) in boys and girls. However, it should be mentioned that mean FSIQ was the same among children from non-fluoridated (108.07) and fluoridated (108.21) areas. It was only after splitting the analysis by sex that the authors obtained an association among boys, for urinary fluoride.

Since the two available prospective studies led to different results (Broadbent et al. 2015; Green et al. 2019), we systematically compared features that may explain the discrepancy (Table 7). A limitation of both studies is the lack of IQ data of the mothers, because parental IQ is a strong confounder. Moreover, it cannot be excluded that the 'outcome' (intelligence) influenced fluoride exposure in the study of Green et al. (2019). An additional limitation of the study performed by Green et al. (2019) is that the intelligence tests have been performed only once between the age of 3 and 4 years, but the exact age of the children at the time point of the test has not been considered in the statistical analysis. This may be problematic, because the IQ of children changes strongly between 3 and 4 years. Moreover, the Wechsler Preschool and Primary Scale of Intelligence Test (WPPSIIII) used in the study provides different sets of subtests for the 2:6-3:11 (years:months) age band and the 4:0-7:7 age band. In contrast, Broadbent et al. (2015) assessed IQ at ages 7, 9, 11, and 13 years and used an average. Therefore, this study evaluated intelligence at older age compared to Green et al. (2019), but obtained a more robust measure of intelligence. Broadbent et al. (2015) used a complete birth cohort with $91 \%$ of eligible births, representing a very high rate. In contrast, only 610 of 2001 pregnant women from the MIREC program were considered in Green et al. (2019); moreover, information on maternal urinary fluoride was missing in a relatively high fraction of the mothers of children of whom IQ was determined. This may represent a possible source of bias. Furthermore, this study used creatinine-adjusted urinary fluoride concentrations to account 
Table 8 Examples of confounding factors that should be considered in epidemiological studies on a possible association between fluoride exposure and intelligence

\author{
Residence, particularly urban versus rural areas \\ Water improvement plants: is fluoride, lead, or arsenic removed from drinking water? \\ Breastfeeding; breastfed children may have higher IQs \\ Confounding by other sources of fluoride (e.g., dental products) than drinking water \\ Background of parents: educational level, socioeconomic status, income, IQ \\ Birth weight; first-born? \\ Intake of iodine \\ Exposure to other chemicals: lead, methylmercury, arsenic, polychlorinated biphenyls
}

for urinary dilution which may cause an additional bias if a study participant suffered from renal problems influencing the IQ (Chen et al. 2018b). Broadbent et al. (2015) studied the influence of possible confounding factors and obtained significant associations of socioeconomic status, breastfeeding, and low birth weight with the IQ. These factors were used to adjust the analysis of community water fluoridation with IQ (Broadbent et al. 2015). As indicated by the authors (Broadbent et al. 2015), a limitation of the study is the fact that individual water-intake level was not directly measured and dietary fluoride was not considered. Green et al. (2019) did not consider breastfeeding and low birth weight as possible confounders (both factors significantly associated with IQ in the study of Broadbent); they considered some of the relevant confounders (city, socioeconomic status, maternal education, race/ethnicity, prenatal secondhand smoke exposure), but did not adjust for others (alcohol consumption and further dietary factors, other sources of fluoride exposure, exact age of children at time point of testing). Furthermore, the study (Green et al. 2019) did not include assessment of children's postnatal fluoride exposure via, e.g., diet, fluoride dentifrice, and/or fluoride tablets, which is considered to be a noteworthy limitation.

Green et al. (2019) present the intelligence of individual children in scatter plots showing maternal urinary fluoride concentration versus IQ (Fig. 3A in Green et al. 2019). Here, male children show a decrease in IQ with increasing maternal urinary fluoride concentration, while female children show a non-significant increase. It should also be noted that the influence of fluoride (increase from the 10th to the 90th percentile of maternal urinary fluoride concentration) of 3.14 IQ in boys is relatively small, compared to the mean difference of around 5 between boys and girls (Green et al. 2019).

Considering the limitations of so far available epidemiological studies, it is difficult to adequately interpret their findings since they present heterogeneous results with a high risk of bias. The only two studies with an appropriate study design (Broadbent et al. 2015; Green et al. 2019) differed in important characteristics (Table 7). The available epidemiological evidence does not provide sufficient arguments to raise concerns with regard to CWF in the range of
$0.7-1.0 \mathrm{mg} / \mathrm{L}$, and to justify the conclusion that fluoride is a human developmental neurotoxicant that should be categorized as similarly problematic as lead or methylmercury at current exposure levels.

For final clarification, prospective studies of even higher quality would be required. All previously reported confounders should be considered (Table 8), including the confounders analyzed in the study of Broadbent et al (2015), namely socioeconomic status, breastfeeding, low birth weight, educational attainment, fluoride toothpaste, and fluoride medication. Furthermore, also the influence of the IQ of the mothers should be analyzed in the future. The association of the confounders with IQ should be presented separately for each confounder, and (at least) all influential confounders should be included into the multivariate analysis. The exact ages of the children should be considered, particularly when IQ tests are performed at young age.

\section{Assessments by other bodies}

The effect of fluoride on human intelligence has already been assessed by different governmental organizations. For example, in 2006 the NRC evaluated epidemiologic studies of populations exposed to different concentrations of fluoride, as well as individual case studies (NRC 2006). According to NRCs evaluation, results of available studies, all performed in China, are not considered relevant for the US population, since most of the publications were brief reports and omitted important study details (e.g., modifications of a standard IQ test were not specified). Nevertheless, due to studies reporting that the average IQ scores were lower in more highly exposed children, the NRC report indicated that additional research is warranted to determine the effects of fluoride on intelligence.

More recently, the Health Research Board of Ireland conducted a systematic review which includes IQ and neurological manifestations (Sutton et al. 2015). The assessment differentiated between fluoride non-endemic areas or areas with CWF and fluoride-endemic areas. The above already discussed prospective cohort study (Broadbent et al. 2015) was identified and considered to have an adequate experimental design (Sutton et al. 2015). For fluoride-endemic 
areas, a summary of the available studies suggests that children living in areas with naturally occurring high fluoride in the water (higher than the CWF levels of $0.4-1 \mathrm{mg} / \mathrm{L}$ ) have a lower IQ compared to children drinking water with naturally occurring levels of fluoridation, which are similar to the CWF levels in Ireland (Sutton et al. 2015). However, the authors stated that the quality of the studies was poor and the study design inadequate to prove or disprove a causal relationship which is in line with the present evaluation.

The National Health and Medical Research Council (NHMRC) of the Australian Government reviewed the epidemiological evidence until 2016. According to the NHMRC Public Statement 2017, there is reliable evidence that community water fluoridation at current Australian levels of $0.6-1.1 \mathrm{mg} / \mathrm{L}$ is not associated with cancer, Down syndrome, cognitive dysfunction, lowered intelligence or hip fracture (NHMRC 2017b).

Furthermore, a retrospective cohort study was conducted by the Institute for Evaluation of Labour Market and Education Policy (IFAU), which is a research institute under the Swedish Ministry of Employment (Aggeborn and Oehman 2017). In this study, the effects of fluoride exposure by drinking water throughout life on cognitive and non-cognitive ability, math test scores, and labor market outcomes were investigated in a nationwide large-scale setting. The Swedish register dataset for the cohorts born 1985-1992 was used, together with drinking water fluoride data. Water fluoride concentrations were estimated utilizing the geographic location of the current residence and this was linked to water supply with known fluoride content. The fluoride data are based on exposure from drinking water which had fluoride levels ranging from effectively 0 up to $1.5 \mathrm{mg} / \mathrm{L}$. Cognitive development was measured through the results from the national math test taken at around the age of 16 years in the ninth grade. Further cognitive and non-cognitive ability measures originated from the Swedish military enlistment (Aggeborn and Oehman 2017). The authors reported that they estimated zero effects on cognitive ability, noncognitive ability, and math test scores for fluoride levels in Swedish drinking water (Aggeborn and Oehman 2017).

\section{In vitro studies}

In vitro studies are usually performed to examine the mechanisms of action of a test compound. In the present review, we analyzed concentration ranges in which fluoride caused cytotoxic effects or influenced other end points, e.g., gene expression. In an explorative approach, these concentrations were compared with human plasma concentrations of fluoride. Importantly, this approach can only be considered as an approximate estimation, because cells cultured in vitro do not necessarily show the same susceptibility as cells organized in tissues in vivo.

We searched the PubMed database with key words, including fluoride and/or $\mathrm{NaF}$ in different combinations with toxic, toxicity, neurotoxic, neurotoxicity, cells, in vitro, neuro-2 A cells, embryonic stem cells, ESC, hESC, neural progenitor cells, NPC, hNPC, neural stem cells, pluripotent stem cells, PSC, hiPSC, primary hippocampal neurons, pheochromocytoma cells, PC 12 cells, BV-2 microglial cells, astrocytes, human neuroblastoma SH-SY5Y cells or human neuroblastoma SK-N-SH cells, neural crest cells, and NCC. In total, 26 in vitro studies on fluoride were found (Table 9).

Cytotoxicity was observed at concentrations of approximately $1 \mathrm{mM}$ in most studies. However, a few studies reported cytotoxic effects at concentrations as low as $0.12 \mathrm{mM}$, such as apoptosis reported in primary hippocampal neurons of mice (Haojun et al. 2012) or in human neuroblastoma cells (Liu et al. 2011); (Table 9). One exception is a more recent study (Zhang et al. 2015b) that reported reduced viability of PC12 cells at the extremely low concentration of $0.005 \mathrm{mM}$ which would be lower than the concentration in drinking water (up to $1.5 \mathrm{mg} / \mathrm{L}$ corresponding to $0.079 \mathrm{mM}$ ). However, the effects of $0.005 \mathrm{mM}$ fluoride on cell viability are inconsistent with regard to incubation period. After $8 \mathrm{~h}$ of fluoride treatment, cell proliferation was slightly decreased, after 12-24 h cells appeared to recover and cell survival rate was higher than that of the control groups, and after $48 \mathrm{~h}$ cell survival rates declined again. This questions the proposed relationship between lower survival rate and fluoride concentration observed after $48 \mathrm{~h}$.

Positive results for readouts other than cytotoxicity, such as gene expression, up-regulation of the inflammatory factor NF-kappaB, or altered intracellular $\mathrm{Ca}^{2+}$ flux, were typically observed between 0.12 and $4 \mathrm{mM}$ depending on the cell system and end point. In contrast, decreased superoxide dismutase (SOD) and increased nitric oxide synthase (NOS) activities were observed in BV-2 microglia cells at the low concentration of $0.024 \mathrm{mM}$, which appears to be an exception and must be interpreted with caution unless reproduced by independent studies (Shuhua et al. 2012).

In summary, the effects on cell systems including cytotoxicity, gene expression, and further readouts were typically obtained at concentrations ranging between 0.1 and $4 \mathrm{mM}$, i.e., orders of magnitude higher than plasma fluoride levels detected in humans. 
Table 9 Fluoride concentrations of in vitro studies that caused positive results in neuronal cells and precursor/stem cells

\begin{tabular}{|c|c|c|c|c|}
\hline \multirow[t]{2}{*}{ Cell type } & \multicolumn{2}{|c|}{ Fluoride concentrations } & \multirow[t]{2}{*}{ Endpoint } & \multirow[t]{2}{*}{ References } \\
\hline & $\begin{array}{l}\text { Highest concen- } \\
\text { tration without } \\
\text { effect }\end{array}$ & $\begin{array}{l}\text { Lowest concen- } \\
\text { tration with } \\
\text { effect }\end{array}$ & & \\
\hline Neuro-2 A cells & $2 \mathrm{mM}$ & $4 \mathrm{mM}$ & Altered expression of neuronal genes & Chen et al. (2017a) \\
\hline Human embryonic stem cells (H9) & $0.5 \mathrm{mM}$ & $\begin{array}{l}1 \mathrm{mM} \\
2 \mathrm{mM}\end{array}$ & $\begin{array}{l}\text { Altered gene expression } \\
\text { Cytotoxicity }\end{array}$ & Fu et al. (2016) \\
\hline Mouse embryonic stem cells (D3) & & $1 \mathrm{mM}$ & Cytotoxicity & Nguyen Ngoc et al. (2012) \\
\hline Primary hippocampal neurons of rats & $0.48 \mathrm{mM}$ & $0.95 \mathrm{mM}$ & Cytotoxicity & Zhang et al. (2007) \\
\hline \multirow[t]{2}{*}{ Primary hippocampal neurons of rats } & & $0.48 \mathrm{mM}$ & $\begin{array}{l}\text { Olive tail moments elevated } \\
\text { Up-regulation of NF-kappaB } \\
(p<0.05) \\
\text { DNA damage }\end{array}$ & Zhang et al. (2008) \\
\hline & & $0.95 \mathrm{mM}$ & $\begin{array}{l}\text { Increase of DNA in the tail } \\
\text { Up-regulation of NF-kappaB } \\
(p>0.05) \\
\text { S-phase cell-cycle arrest }\end{array}$ & \\
\hline \multirow[t]{3}{*}{ Primary hippocampal neurons of rats } & & $0.48 \mathrm{mM}$ & $\begin{array}{l}\text { NCAM-140 expression level } \\
\text { decreased }\end{array}$ & Xia et al. (2007) \\
\hline & & $0.95 \mathrm{mM}$ & NCAM expression level decreased & \\
\hline & & $1.91 \mathrm{mM}$ & $\begin{array}{l}\text { NCAM-120 expression level } \\
\text { decreased } \\
\text { Cell survivor decreased }\end{array}$ & \\
\hline $\begin{array}{l}\text { Primary hippocampal neurons of } \\
\text { mouse }\end{array}$ & & $0.12 \mathrm{mM}$ & $\begin{array}{l}\text { Intracellular } \mathrm{Ca}^{2+} \text { fluxes }>\text { increase } \\
\text { of intercellular concentration } \\
\text { Increase of apoptotic peaks }\end{array}$ & Haojun et al. (2012) \\
\hline \multirow{2}{*}{$\begin{array}{l}\text { PC12 cells (pheochromocytoma } \\
\text { cells) }\end{array}$} & & $0.5 \mathrm{mM}$ & Cytotoxicity (8 h) & Ke et al. (2016) \\
\hline & & $1 \mathrm{mM}$ & $\begin{array}{l}\text { Cytotoxicity }(2 \mathrm{~h}) \\
\text { Increased expression levels of } \\
\text { apoptosis-related proteins (p-elF, } \\
\text { PARP) } \\
\text { Increased expression levels of ERS- } \\
\text { related protein XBP-A }\end{array}$ & \\
\hline \multirow[t]{3}{*}{$\begin{array}{l}\text { PC } 12 \text { cells (pheochromocytoma } \\
\text { cells) }\end{array}$} & & $0.005 \mathrm{mM}$ & $\begin{array}{l}\text { Intracellular ROS increase } \\
\text { Apoptotic cells } \\
\text { Cytotoxicity }(48 \mathrm{~h})\end{array}$ & Zhang et al. (2015b) \\
\hline & & $0.05 \mathrm{mM}$ & $\begin{array}{l}\text { Apoptotic cells } \\
\text { Cytotoxicity }(8 \mathrm{~h})\end{array}$ & \\
\hline & & $0.5 \mathrm{mM}$ & $\begin{array}{l}\text { Apoptotic cells } \\
\text { Cytotoxicity }(2 \mathrm{~h})\end{array}$ & \\
\hline $\begin{array}{l}\text { PC } 12 \text { cells (pheochromocytoma } \\
\text { cells) }\end{array}$ & $0.024 \mathrm{mM}$ & $0.24 \mathrm{mM}$ & $\begin{array}{l}\text { Decline of MTT reduction } \\
\text { Protein oxidation }\end{array}$ & Shan et al. (2004) \\
\hline $\begin{array}{l}\text { PC } 12 \text { cells (pheochromocytoma } \\
\text { cells) }\end{array}$ & $0.024 \mathrm{mM}$ & $0.24 \mathrm{mM}$ & $\begin{array}{l}\text { Selective decreases in the number of } \\
\text { nAChRs }\end{array}$ & Chen et al. (2003) \\
\hline $\begin{array}{l}\text { PC } 12 \text { cells (pheochromocytoma } \\
\text { cells) }\end{array}$ & $0.024 \mathrm{mM}$ & $0.24 \mathrm{mM}$ & Increase of total inositol phosphates & Bencherif and Lukas (1991) \\
\hline BV-2 microglia cells & $0.5 \mathrm{mM}$ & $\begin{array}{l}1 \mathrm{mM} \\
2 \mathrm{mM}\end{array}$ & $\begin{array}{l}\text { Increase of IL- } 6 \text { concentration } \\
\text { Significant decrease of cell viability } \\
(12 \mathrm{~h}) \\
\text { SOD activity lower } \\
\text { Increase of TNF- } \alpha \text { level }\end{array}$ & Chen et al. (2017b) \\
\hline BV-2 microglia cells & $0.024 \mathrm{mM}$ & $\begin{array}{l}0.119 \mathrm{mM} \\
1.19 \mathrm{mM}\end{array}$ & $\begin{array}{l}\text { Increased JNK phosphorylation level } \\
\text { Cytotoxicity } \\
\text { Increase of NO release } \\
\text { Increase of TNF } \alpha \text { release }\end{array}$ & Yan et al. (2013) \\
\hline
\end{tabular}


Table 9 (continued)

\begin{tabular}{|c|c|c|c|c|}
\hline \multirow[t]{2}{*}{ Cell type } & \multicolumn{2}{|c|}{ Fluoride concentrations } & \multirow[t]{2}{*}{ Endpoint } & \multirow[t]{2}{*}{ References } \\
\hline & $\begin{array}{l}\text { Highest concen- } \\
\text { tration without } \\
\text { effect }\end{array}$ & $\begin{array}{l}\text { Lowest concen- } \\
\text { tration with } \\
\text { effect }\end{array}$ & & \\
\hline \multirow[t]{3}{*}{ BV-2 microglia cells } & & $0.024 \mathrm{mM}$ & $\begin{array}{l}\text { SOD activities decreased } \\
\text { NOS (synthesizing NO) increased }\end{array}$ & Shuhua et al. (2012) \\
\hline & & $0.119 \mathrm{mM}$ & $\begin{array}{l}\text { Change into activated microglia } \\
\text { Up-regulated OX- } 42 \text { expression }\end{array}$ & \\
\hline & & $1.19 \mathrm{mM}$ & Cytotoxicity & \\
\hline Bergmann glia cells & \multirow[t]{5}{*}{$0.5 \mathrm{mM}$} & $1 \mathrm{mM}$ & Cytotoxicity & Flores-Mendez et al. (2014) \\
\hline Hippocampal slices of rat and mouse & & 1 to about $5 \mathrm{mM}$ & $\begin{array}{l}\text { Activation of MAP kinase } \\
\text { Followed by volume reduction }\end{array}$ & Lee et al. (2016) \\
\hline Astrocytes of rat cerebral cortex & & $1 \mathrm{mM}$ & $\begin{array}{l}\text { Cell cycle arrest transited from } \\
\mathrm{S} \text { phase to } \mathrm{G} 2 / \mathrm{M} \text { phase } \\
\text { Increase of subG1 cells }\end{array}$ & Li et al. (2010) \\
\hline \multirow[t]{2}{*}{$\begin{array}{l}\text { Human neuroblastoma } \\
\text { SH-SY5 Y cells }\end{array}$} & & $0.48 \mathrm{mM}$ & $\begin{array}{l}\text { Drp1 expression increased } \\
\text { Fis } 1 \text { expression reduced } \\
\text { Mfn1 protein increased } \\
\text { Mfn2 protein increased }\end{array}$ & \multirow[t]{2}{*}{ Zhao et al. (2019) } \\
\hline & & $0.95 \mathrm{mM}$ & $\begin{array}{l}\text { Drp1 expression reduced } \\
\text { Fis } 1 \text { expression reduced } \\
\text { Mfn1 expression increased } \\
\text { Mfn2 expression increased }\end{array}$ & \\
\hline $\begin{array}{l}\text { Human neuroblastoma } \\
\text { SH-SY5 Y cells }\end{array}$ & $0.71 \mathrm{mM}$ & $0.95 \mathrm{mM}$ & $\begin{array}{l}\text { Cytotoxicity } \\
\text { Induced apoptosis }\end{array}$ & Tu et al. (2018) \\
\hline \multirow[t]{2}{*}{$\begin{array}{l}\text { Human neuroblastoma } \\
\text { SH-SY5 Y cells }\end{array}$} & \multirow[t]{2}{*}{$0.48 \mathrm{mM}$} & $0.95 \mathrm{mM}$ & $\begin{array}{l}\text { SYN expression reduced } \\
\text { TrkB expression reduced } \\
\text { p-Erk expression increased }\end{array}$ & \multirow[t]{2}{*}{ Chen et al. $(2018 \mathrm{a}, \mathrm{b})$} \\
\hline & & $1.43 \mathrm{mM}$ & $\begin{array}{l}\text { PSD } 95 \text { protein expression reduced } \\
\text { BDNF protein expression increased }\end{array}$ & \\
\hline $\begin{array}{l}\text { Human neuroblastoma } \\
\text { SH-SY5 Y cells }\end{array}$ & $0.48 \mathrm{mM}$ & $0.95 \mathrm{mM}$ & Autophagic vesicles decreased & Tang et al. (2017) \\
\hline $\begin{array}{l}\text { Human neuroblastoma } \\
\text { SH-SY5 Y cells }\end{array}$ & $0.48 \mathrm{mM}$ & $0.95 \mathrm{mM}$ & LDH levels higher & Xu et al. (2013) \\
\hline $\begin{array}{l}\text { Human neuroblastoma } \\
\text { SH-SY5 Y cells }\end{array}$ & $0.48 \mathrm{mM}$ & $0.95 \mathrm{mM}$ & $\begin{array}{l}\text { Cytotoxicity } \\
\text { Percentages of apoptosis higher } \\
\text { Activity of caspase- } 3 \text { higher } \\
\text { mRNA expression levels for Fas, } \\
\text { Fas-L, and caspases ( } 3 \text { and } 8 \text { ) } \\
\text { higher }\end{array}$ & Xu et al. (2011) \\
\hline \multirow[t]{2}{*}{$\begin{array}{l}\text { Human neuroblastoma } \\
\text { SH-SY5 Y cells }\end{array}$} & & $0.12 \mathrm{mM}$ & $\begin{array}{l}\text { Cytotoxicity }(24 \mathrm{~h}) \\
\text { Expression of phospho-JNK }\end{array}$ & Liu et al. (2011) \\
\hline & & $1.91 \mathrm{mM}$ & $\begin{array}{l}\text { Cytotoxicity }(8 \mathrm{~h}) \\
\text { MTT reduction }\end{array}$ & \\
\hline $\begin{array}{l}\text { Human neuroblastoma } \\
\text { SK-N-SH cells }\end{array}$ & & $\sim 2.5 \mathrm{mM}$ & $\begin{array}{l}\text { Stimulation of } \\
\text { inositol phosphates release }\end{array}$ & Fisher et al. (1993) \\
\hline
\end{tabular}

\section{Conclusions}

For risk evaluation, we compared human exposure (expressed as mg fluoride/kg b.w./day) and no observed adverse effect levels (NOAELs) derived from animal experiments (also as mg fluoride/kg b.w./day). The adequate daily fluoride intake (AI) is $50 \mu \mathrm{g} / \mathrm{kg}$ b.w./day (EFSA 2013), and in the EU, the median fluoride intake from water has been estimated to be $1.86 \mu \mathrm{g} / \mathrm{kg}$ b.w./day, with reports of rare extreme levels of $120 \mu \mathrm{g} / \mathrm{kg}$ b.w./day (EFSA 2013) (Fig. 1). This extreme scenario (120 $\mu \mathrm{g} / \mathrm{kg}$ b.w./day) corresponds to a $70 \mathrm{~kg}$ person drinking $2 \mathrm{~L}$ with $4.2 \mathrm{mg} / \mathrm{L}$ fluoride (or slightly lower concentrations if one considers the additional contribution by food and dental care products). The average intake 
of fluoride from food in European countries is approximately $5-28 \mu \mathrm{g} / \mathrm{kg}$ b.w./day and toothpaste may contribute approximately $1.4 \mu \mathrm{g} / \mathrm{kg}$ b.w./day in adults and $11.5 \mu \mathrm{g} / \mathrm{kg}$ b.w./day in children (EFSA 2013). Therefore, it seems pragmatic to use the recommended daily intake of $50 \mu \mathrm{g} / \mathrm{kg}$ b.w./day to compare NOAELs from animal experiments, while also considering the extreme scenario with $120 \mu \mathrm{g} / \mathrm{kg}$ b.w./day. The lowest reported NOAEL from a well-designed chronic animal toxicity study investigating systemic effects was $2.5 \mathrm{mg} / \mathrm{kg}$ b.w./day fluoride (Fig. 2), resulting in a margin of exposure (MoE) of 50 compared to the adequate daily intake ( $50 \mu \mathrm{g} / \mathrm{kg}$ b.w./day). For the extreme scenario of $120 \mu \mathrm{g} / \mathrm{kg}$ b.w./day, the MoE would be 21 . With the NOAEL of $8.5 \mathrm{mg} / \mathrm{kg}$ b.w./day as point of departure for developmental toxicity, the adequate daily intake of $50 \mu \mathrm{g} / \mathrm{kg}$ b.w./day resulted in a high MoE of 170 (Fig. 2). Due to serious study limitations, the lower LOAELs/NOAELs reported in some recent studies on developmental or neurobehavioral toxicity are not considered appropriate to derive an MoE, but warrant further investigations.

In addition to the above-described approach, internal fluoride exposure (plasma concentrations) was compared to concentrations that caused cytotoxicity or other test results (e.g., gene expression changes) in vitro in neuronal or precursor/stem cells (Table 9). Most in vitro studies resulted in measurable results at approximately $1 \mathrm{mM}$ fluoride with a range of approximately $0.1-4 \mathrm{mM}$, which is 333 -fold higher than the highest fluoride concentration of $3 \mu \mathrm{M}$ reported in healthy adults. For individuals consuming drinking water with extremely high fluoride concentrations ( $>8 \mathrm{mg}$ fluoride/L), plasma concentrations of approximately $10 \mu \mathrm{M}$ $\mathrm{F}^{-}$have been reported (Fig. 1) (Jha et al. 1982). This is still 100-fold below the critical in vitro cytotoxic concentration of $1 \mathrm{mM}$ fluoride. The particularly low concentration of $0.1 \mathrm{mM}$ fluoride reported in some neuronal cells to induce apoptotic effects in vitro (Haojun et al. 2012; Liu et al. 2011) would yield an 'in vitro MoE' of 33 compared to the plasma fluoride concentration of $3 \mu \mathrm{M}$, still more than one order of magnitude higher than plasma fluoride concentrations found in healthy humans. Furthermore, fluoride concentrations in human brain tissue have been reported to be lower than those reported in plasma (Taves et al. 1983). It also should be taken into consideration that the in vitro data presented here were obtained in cultivated neuronal or precursor cells, which may show different susceptibilities compared to tissues in vivo. Nevertheless, this in vitro approach allows a first assessment of the order of magnitude where adverse effects may be expected. It thus supports the NOAEL based risk evaluation described above.

This review considered experimental in vitro and animal studies as well as epidemiological studies. Of note, the majority of epidemiological studies reported an association between lower measures of intelligence and high fluoride exposure. However, the experimental evidence suggests that current exposure to fluoride, even for individuals with relatively high fluoride intake, is clearly below levels that lead to adverse effects in vitro or in animals. The discrepancy between experimental and epidemiological evidence may be reconciled with deficiencies inherent in most epidemiological studies on a putative association between fluoride and intelligence, especially with respect to adequate consideration of potential confounders. The only two prospective cohort studies conducted in areas with community water fluoridation that considered possible confounding factors reported conflicting results (Broadbent et al. 2015; Green et al. 2019). Overall, despite the remaining uncertainties, and based on the totality of evidence the present review does not support the presumption that fluoride should be considered as a human developmental neurotoxicant at current exposure levels in European countries.

\section{Research needs}

For a comprehensive risk assessment, further research is needed. Human exposure to fluoride has already been studied in the past (EFSA 2013; FSAI 2018), but to enable a more accurate assessments of total fluoride intake and of fluoride intake from different sources it is recommended to systematically analyze the fluoride content of foods, beverages, and water for human consumption in the EU using a standardized methodology. Furthermore, the validation of biomarkers of actual and chronic fluoride intake could contribute to an overall exposure assessment. In recent years, several developmental and neurobehavioral animal studies reported unusually low NOAELs and LOAELs. However, a critical analysis of these studies showed that they often did not comply with state-of-the-art scientific quality criteria. For clarification, sufficiently powered high-quality animal studies would be helpful. Similarly, high-quality prospective epidemiological studies are required that adequately control for any confounding factors.

Acknowledgements Open Access funding provided by Projekt DEAL. This study was an activity of the Senate Commission on Food Safety (SKLM) of the German Research Foundation (DFG). The authors wish to thank the DFG for their continuous support of the SKLM Commission.

Funding This work was financially supported by the Deutsche Forschungsgemeinschaft (DFG), HE 2509/15-11.

\section{Compliance with ethical standards}

Conflict of interest The authors declare that they have no conflict of interest. 
Ethical approval This article does not contain any studies with human participants or animals performed by any of the authors.

Open Access This article is licensed under a Creative Commons Attribution 4.0 International License, which permits use, sharing, adaptation, distribution and reproduction in any medium or format, as long as you give appropriate credit to the original author(s) and the source, provide a link to the Creative Commons licence, and indicate if changes were made. The images or other third party material in this article are included in the article's Creative Commons licence, unless indicated otherwise in a credit line to the material. If material is not included in the article's Creative Commons licence and your intended use is not permitted by statutory regulation or exceeds the permitted use, you will need to obtain permission directly from the copyright holder. To view a copy of this licence, visit http://creativecommons.org/licenses/by/4.0/.

\section{References}

Adamek E, Pawlowska-Goral K, Bober K (2005) In vitro and in vivo effects of fluoride ions on enzyme activity. Ann Acad Med Stetin 51(2):69-85

AFSSA (2003) Rapport du comité d'experts spécialisé "eaux" concernant la proposition de fixation d'une valeur limite du fluor dans les eaux minérales naturelles. Agence Française de Sécurité Sanitaire des Aliments, Maisons-Alfort

Aggeborn L, Oehman M (2017) The effects of fluoride in drinking water. Uppsala: Institute for Evaluation of Labour Market and Education Policy, p. 1-83. https://www.ifau.se/globalassets/pdf/ se/2017/wp2017-20-the-effects-of-fluoride-in-the-drinking-water .pdf.

Anuradha CD, Kanno S, Hirano S (2001) Oxidative damage to mitochondria is a preliminary step to caspase-3 activation in fluoride-induced apoptosis in HL-60 cells. Free Radic Biol Med 31(3):367-373

Aravind A, Dhanya RS, Narayan A, Sam G, Adarsh VJ, Kiran M (2016) Effect of fluoridated water on intelligence in 10-12-year-old school children. J Int Soc Prev Community Dent 6(3):S237-S242

ATSDR (1993) Agency for toxic substances and disease registry; toxicological profile for fluorides, hydrogen fluoride, and fluorine (F). TP-91/17. US Department of Health and Human Services. Public Health Service, Atlanta, GA. https://books.google.de/books ?id=GU8Lj0_pWLsC\&printsec $=$ frontcover \&hl=de\&sourc $\mathrm{e}=$ gbs_ge_summary_r $\& \mathrm{cad}=0 \# \mathrm{v}=$ onepage $\& \mathrm{q} \& \mathrm{f}=\mathrm{false}$.

ATSDR (2003) Agency for toxic substances and disease registry; toxicological profile for fluorides, hydrogen fluoride, and fluorine. US Department of Health and Human Services. Public Health Service, Atlanta, GA. https://www.atsdr.cdc.gov/toxprofiles/tp11. pdf.

Barbier O, Arreola-Mendoza L, Del Razo LM (2010) Molecular mechanisms of fluoride toxicity. Chem Biol Interact 188(2):319-333

Bartos M, Gumilar F, Gallegos CE et al (2018) Alterations in the memory of rat offspring exposed to low levels of fluoride during gestation and lactation: Involvement of the alpha7 nicotinic receptor and oxidative stress. Reprod Toxicol 81:108-114

Basha PM, Rai P, Begum S (2011) Fluoride toxicity and status of serum thyroid hormones, brain histopathology, and learning memory in rats: a multigenerational assessment. Biol Trace Elem Res 144(1-3): 1083-1094

Bashash M, Thomas D, Hu H et al (2017) Prenatal fluoride exposure and cognitive outcomes in children at 4 and 6-12 years of age in Mexico. Environ Health Perspect 125(9):097017

Becker W, Bruce A (1981) Fluoride intake from food. Vår Föda 33:198-261
Bencherif M, Lukas RJ (1991) Differential sensitivity of phosphoinositide metabolism to sodium fluoride and carbachol treatments in PC12 cells. Mol Cell Neurosci 2(5):377-383

Bergmann R (1994) Fluorid in der Ernährung des Menschen. Biologische Bedeutung für den wachsenden Organismus. Habilitationsschrift Medical Faculty, Free University Berlin, Berlin

BMG/UBA (2015) Bericht des Bundesministeriums für Gesundheit und des Umweltbundesamtes an die Verbraucherinnen und Verbraucher über die Qualität von Wasser für den menschlichen Gebrauch (Trinkwasser) in Deutschland. Berichtszeitraum: 1. Jan. 2011 bis 31. Dez. 2013. In: Umweltbundesamt (Hrsg.): Umwelt \& Gesundheit, 02/2015 (https://www.umweltbund esamt.de/sites/default/files/medien/378/publikationen/umwel t_und_gesundheit_02_2015_trinkwasserbericht_des_bmg.pdf).

Boink AB, Wemer J, Meulenbelt J, Vaessen HA, de Wildt DJ (1994) The mechanism of fluoride-induced hypocalcaemia. Hum Exp Toxicol 13(3):149-155

Bouaziz H, Croute F, Boudawara T, Soleilhavoup JP, Zeghal N (2007) Oxidative stress induced by fluoride in adult mice and their suckling pups. Exp Toxicol Pathol 58(5):339-349

Bouchard MF, Sauve S, Barbeau B et al (2011) Intellectual impairment in school-age children exposed to manganese from drinking water. Environ Health Perspect 119(1):138-143

Broadbent JM, Thomson WM, Ramrakha S et al (2015) Community water fluoridation and intelligence: prospective study in New Zealand. Am J Public Health 105(1):72-76

Buzalaf MA, Whitford GM (2011) Fluoride metabolism. Monogr Oral Sci 22:20-36

Caldera R, Chavinie J, Fermanian J, Tortrat D, Laurent AM (1988) Maternal-fetal transfer of fluoride in pregnant women. Biol Neonate 54(5):263-269

Carrington C, Devleesschauwer B, Gibb HJ, Bolger PM (2019) Global burden of intellectual disability resulting from dietary exposure to lead, 2015. Environ Res 172:420-429

Chan JT, Koh SH (1996) Fluoride content in caffeinated, decaffeinated and herbal teas. Caries Res 30(1):88-92

Chen J, Niu Q, Xia T et al (2018) ERK1/2-mediated disruption of BDNF-TrkB signaling causes synaptic impairment contributing to fluoride-induced developmental neurotoxicity. Toxicology 410:222-230

Chen K, Didsbury M, van Zwieten A et al (2018) Neurocognitive and educational outcomes in children and adolescents with CKD. A systematic review and meta-analysis. Clin J Am Soc Nephrol 13(3):387-397

Chen J, Shan KR, Long YG, Wang YN, Nordberg A, Guan ZZ (2003) Selective decreases of nicotinic acetylcholine receptors in PC 12 cells exposed to fluoride. Toxicology 183(1-3):235-242

Chen L, Ning H, Yin Z et al (2017) The effects of fluoride on neuronal function occurs via cytoskeleton damage and decreased signal transmission. Chemosphere 185:589-594

Chen R, Zhao LD, Liu H et al (2017) Fluoride induces neuroinflammation and alters wnt signaling pathway in BV2 microglial cells. Inflammation 40(4):1123-1130

Chinoy NJ, Patel TN (2001) Effects of sodium fluoride and aluminum chloride on ovary and uterus of mice and their reversal by some antidotes. Fluoride 34(1):9-20

Chlubek D, Grucka-Mamczar E, Birkner E, Polaniak R, StawiarskaPięta B, Duliban H (2003) Activity of pancreatic antioxidative enzymes and malondialdehyde concentrations in rats with hyperglycemia caused by fluoride intoxication. J Trace Elem Med Bio 17(1):57-60

Choi AL, Sun G, Zhang Y, Grandjean P (2012) Developmental fluoride neurotoxicity: a systematic review and meta-analysis. Environ Health Perspect 120(10):1362-1368 
Choi AL, Zhang Y, Sun G et al (2015) Association of lifetime exposure to fluoride and cognitive functions in Chinese children: a pilot study. Neurotoxicol Teratol 47:96-101

Cicek E, Aydin G, Akdogan M, Okutan H (2005) Effects of chronic ingestion of sodium fluoride on myocardium in a second generation of rats. Hum Exp Toxicol 24(2):79-87

Collins TF, Sprando RL, Black TN et al (2001a) Multigenerational evaluation of sodium fluoride in rats. Food Chem Toxicol 39(6):601-613

Collins TF, Sprando RL, Black TN et al (2001) Developmental toxicity of sodium fluoride measured during multiple generations. Food Chem Toxicol 39(8):867-876

Collins TF, Sprando RL, Shackelford ME et al (1995) Developmental toxicity of sodium fluoride in rats. Food Chem Toxicol 33(11):951-960

Das K, Mondal NK (2016) Dental fluorosis and urinary fluoride concentration as a reflection of fluoride exposure and its impact on IQ level and BMI of children of Laxmisagar, Simlapal Block of Bankura District, W.B., India. Environ Monit Assess 188(4): 218.

Dirks OB, Jongeling-Eijndhoven JM, Flissebaalje TD, Gedalia I (1974) Total and free ionic fluoride in human and cow's milk as determined by gas-liquid chromatography and the fluoride electrode. Caries Res 8(2):181-186

Dong Y-T, Wei N, Qi X-L et al (2017) Attenuating effect of vitamin $\mathrm{E}$ on the deficit of learning and memory of rats with chronic fluorosis: The mechanism may involve muscarinic acetylcholine receptors. Fluoride 50(3):354-364

Duan Q, Jiao J, Chen X, Wang X (2018) Association between water fluoride and the level of children's intelligence: a dose-response meta-analysis. Public Health 154:87-97

Dunipace AJ, Brizendine EJ, Zhang W et al (1995) Effect of aging on animal response to chronic fluoride exposure. J Dent Res 74(1):358-368

EFSA (2005) Opinion of the scientific panel on dietetic products, nutrition and allergies on a request from the Commission related to the tolerable upper intake level of fluoride (Request No EFSAQ-2003-018). EFSA J 192:1-65

EFSA (2008) Calcium fluoride as a source of fluoride added for nutritional purposes to food supplements. EFSA J 882:1-15

EFSA (2012) Scientific Committee; Guidance on selected default values to be used by the EFSA Scientific Committee, Scientific Panels and Units in the absence of actual measured data. EFSA J 10(3):2579

EFSA (2013) Panel on dietetic products, nutrition; scientific opinion on dietary reference values for fluoride. EFSA J 11(8):3332

Eichler HG, Lenz K, Fuhrmann M, Hruby K (1982) Accidental ingestion of $\mathrm{NaF}$ tablets by children-report of a poison control center and one case. Int J Clin Pharmacol Ther Toxicol 20(7):334-338

Ekstrand J, Alvan G, Boreus LO, Norlin A (1977) Pharmacokinetics of fluoride in man after single and multiple oral doses. Eur J Clin Pharmacol 12(4):311-317

Ekstrand J, Boreus L, De Chateau P (1981) No evidence of transfer of fluoride from plasma to breast milk. Br Med J 283(6294):761-762

Ekstrand J, Whitford G (1988) Fluoride metabolism. In: Ekstrand J, Fejerskov O, Silverstone LM (eds) Fluoride in dentistry. Munksgaard, Copenhagen, pp 150-170

EPA (2010) Fluoride: exposure and relative source contribution analysis. 820-R-10-015. Washington: US Environmental ProtectionAgency. Office of Water, Health and Ecological Criteria Division. https://www.epa.gov/sites/production/files/2019-03/documents/ fluoride-exposure-relative-report.pdf.

EVM (2001) Review of fluoride. Expert group on vitamins and minerals. EVM/01/03/P.
Feldman V (2014) Neurodevelopmental toxicity: still more questions than answers. Lancet Neurol 13(7):645-646

Fisher SK, McEwen E, Kunkle C, Thompson AK, Slowiejko D (1993) Contribution of $\mathrm{G}$ protein activation to fluoride stimulation of phosphoinositide hydrolysis in human neuroblastoma cells. J Neurochem 60(5):1800-1805

Flora SJ, Mittal M, Mishra D (2009) Co-exposure to arsenic and fluoride on oxidative stress, glutathione linked enzymes, biogenic amines and DNA damage in mouse brain. J Neurol Sci 285(1-2):198-205

Flores-Mendez M, Ramirez D, Alamillo N, Hernandez-Kelly LC, Del Razo LM, Ortega A (2014) Fluoride exposure regulates the elongation phase of protein synthesis in cultured Bergmann glia cells. Toxicol Lett 229(1):126-133

FSAI (2018) Total diet study 2014-2016: Assessment of dietary exposure to fluoride in adults and children in Ireland. Report of the Scientific Committee of the Food Safety Authority of Ireland. https://www.fsai.ie/news_centre/tds_fluoride_30042018.html.

Fu X, Xie FN, Dong P, Li QC, Yu GY, Xiao R (2016) High-dose fluoride impairs the properties of human embryonic stem cells via JNK signaling. PLoS ONE 11(2):e0148819

Garcia-Montalvo EA, Reyes-Perez H, Del Razo LM (2009) Fluoride exposure impairs glucose tolerance via decreased insulin expression and oxidative stress. Toxicology 263(2-3):75-83

Gardiner IM, de Belleroche J (1990) Modulation of gamma-aminobutyric acid release in cerebral cortex by fluoride, phorbol ester, and phosphodiesterase inhibitors: differential sensitivity of acetylcholine release to fluoride and $\mathrm{K}+$ channel blockers. J Neurochem 54(4):1130-1135

Ge Y, Chen L, Yin Z et al (2018) Fluoride-induced alterations of synapse-related proteins in the cerebral cortex of ICR offspring mouse brain. Chemosphere 201:874-883

Gelinas J, Allukian M Jr (2014) Neurodevelopmental toxicity: still more questions than answers. Lancet Neurol 13(7):647-648

Grandjean P, Landrigan PJ (2014) Neurobehavioural effects of developmental toxicity. Lancet Neurol 13(3):330-338

Green R, Lanphear B, Hornung R et al (2019) Association between maternal fluoride exposure during pregnancy and IQ scores in offspring in Canada. JAMA Pediatr 173(10):940-948

Guo H, Kuang P, Luo Q et al (2017) Effects of sodium fluoride on blood cellular and humoral immunity in mice. Oncotarget $8(49): 85504-85515$

Gutknecht J, Walter A (1981) Hydrofluoric and nitric acid transport through lipid bilayer membranes. Biochim Biophys Acta 644(1):153-156

Haojun Z, Yaoling W, Ke Z, Jin L, Junling W (2012) Effects of NaF on the expression of intracellular $\mathrm{Ca} 2+$ fluxes and apoptosis and the antagonism of taurine in murine neuron. Toxicol Mech Methods 22(4):305-308

Heindel JJ, Bates HK, Price CJ, Marr MC, Myers CB, Schwetz BA (1996) Developmental toxicity evaluation of sodium fluoride administered to rats and rabbits in drinking water. Fundam Appl Toxicol 30(2):162-177

Hibbeln JR, Davis JM, Steer C et al (2007) Maternal seafood consumption in pregnancy and neurodevelopmental outcomes in childhood (ALSPAC study): an observational cohort study. Lancet 369(9561):578-585

Horgan AM, Lagrange MT, Copenhaver PF (1994) Developmental expression of $\mathrm{G}$ proteins in a migratory population of embryonic neurons. Development 120(4):729-742

IARC (1982) International Agency for Research on Cancer; Some aromatic amines, anthraquinones and nitroso compounds, and inorganic fluorides used in drinking-water and dental preparations. Lyon 
IPCS (2002) International programme on chemical safety; fluorides (Environmental Health Criteria 227). World Health Organization, Geneva

Izquierdo-Vega JA, Sanchez-Gutierrez M, Del Razo LM (2008) Decreased in vitro fertility in male rats exposed to fluorideinduced oxidative stress damage and mitochondrial transmembrane potential loss. Toxicol Appl Pharmacol 230(3):352-357

Jha M, Susheela AK, Krishna N, Rajyalakshmi K, Venkiah K (1982) Excessive ingestion of fluoride and the significance of sialic acid: glycosaminoglycans in the serum of rabbit and human subjects. J Toxicol Clin Toxicol 19(10):1023-1030

Jortner BS (2006) The return of the dark neuron. A histological artifact complicating contemporary neurotoxicologic evaluation. Neurotoxicology 27(4):628-634

Karimzade S, Aghaei M, Mahvi AH (2014) Investigation of intelligence quotient in 9-12-year-old children exposed to high and low-drinking water fluoride in West Azerbaijan province. Iran Fluoride 47(1):9-14

Ke L, Zheng X, Sun Y, Ouyang W, Zhang Z (2016) Effects of sodium fluoride on lipid peroxidation and PARP, XBP-1 expression in PC12 cell. Biol Trace Elem Res 173(1):161-167

Khan SA, Singh RK, Navit S et al (2015) Relationship between dental fluorosis and intelligence quotient of school going children in and around Lucknow district: a cross-sectional study. J Clin Diagn Res 9(11):10-15

Knox EG (1985) Fluoridation of water and cancer: A review of the epidemiological evidence: Report of the working party. Her Majesty's Stationery Office

Koparal E, Ertugrul F, Oztekin K (2000) Fluoride levels in breast milk and infant foods. J Clin Pediatr Dent 24(4):299-302

Kubota K, Lee DH, Tsuchiya M et al (2005) Fluoride induces endoplasmic reticulum stress in ameloblasts responsible for dental enamel formation. J Biol Chem 280(24):23194-23202

Kundu H, Basavaraj P, Singla A, Gupta R, Singh K, Jain S (2015) Effect of fluoride in drinking water on children's intelligence in high and low fluoride areas of Delhi. J Indian Assoc Public Health Dent 13(2):116-121

Lee J-H, Jung J-Y, Jeong Y-J et al (2008) Involvement of both mitochondrial-and death receptor-dependent apoptotic pathways regulated by Bcl-2 family in sodium fluoride-induced apoptosis of the human gingival fibroblasts. Toxicology 243(3):340-347

Lee J, Han YE, Favorov O, Tommerdahl M, Whitsel B, Lee CJ (2016) Fluoride induces a volume reduction in CA1 hippocampal slices via map kinase pathway through volume regulated anion channels. Exp Neurobiol 25(2):72-78

Li H, Huang H, Xu Y, Gao Y, Liu Z (2010) Toxic effects of fluoride on rat cerebral cortex astrocytes in vitro. Wei Sheng Yan Jiu 39(1):86-88

Li X, Zhang J, Niu R, Manthari RK, Yang K, Wang J (2019) Effect of fluoride exposure on anxiety- and depression-like behavior in mouse. Chemosphere 215:454-460

Lidbeck WL, Hill IB, Beeman JA (1943) Acute sodium fluoride poisoning. JAMA 121(11):826-827

Liu YJ, Guan ZZ, Gao Q, Pei JJ (2011) Increased level of apoptosis in rat brains and SH-SY5Y cells exposed to excessive fluoridea mechanism connected with activating JNK phosphorylation. Toxicol Lett 204(2-3):183-189

Marthaler TM (2013) Salt fluoridation and oral health. Acta Med Acad 42(2):140-155

McPherson CA, Zhang G, Gilliam R et al (2018) An evaluation of neurotoxicity following fluoride exposure from gestational through adult ages in long-evans hooded rats. Neurotox Res 34(4):781-798

Mendoza-Schulz A, Solano-Agama C, Arreola-Mendoza L et al (2009) The effects of fluoride on cell migration, cell proliferation, and cell metabolism in GH4C1 pituitary tumour cells. Toxicol Lett 190(2):179-186

Mesram N, Nagapuri K, Banala RR, Nalagoni CR, Karnati PR (2017) Quercetin treatment against $\mathrm{NaF}$ induced oxidative stress related neuronal and learning changes in developing rats. J King Saud Univ Sci 29:221-229

Mondal D, Dutta G, Gupta S (2016) Inferring the fluoride hydrogeochemistry and effect of consuming fluoride-contaminated drinking water on human health in some endemic areas of Birbhum district. West Bengal Environ Geochem Health 38(2):557-576

Mustafa DE, Younis UM, Elhaga SAA (2018) The relationship between the fluoride levels in drinking water and the schooling performance of children in rural areas of Khartoum State. Sudan Fluoride 51(2):102-113

Nagarajappa R, Pujara P, Sharda AJ et al (2013) Comparative assessment of intelligence quotient among children living in high and low fluoride areas of Kutch, India-a pilot study. Iran J Public Health 42(8):813-818

Naik SP, Bankur PK, Sathe S, Haris PMM, Kadar N, Satyanarayan A (2018) Impact of fluoridated water on intelligence quotient levels of school children: a exploratory study. Int J Oral Care Res 6(1):63-66

Nakamoto T, Rawls HR (2018) Fluoride exposure in early life as the possible root cause of disease in later life. J Clin Pediatr Dent 42(5):325-330

Narayana MV, Chinoy NJ (1994) Effect of fluoride on rat testicular steroidogenesis. Fluoride 27(1):7-12

Neelam K, Suhasini R, Sudhakar R (1987) Incidence of prevalence of infertility among married male members of endemic fluorosis district of Andhra Pradesh. In: Proceedings of a conference of the international society of fluoride research, Switzerland (Nyon) (Abstract)

Nguyen Ngoc TD, Son YO, Lim SS et al (2012) Sodium fluoride induces apoptosis in mouse embryonic stem cells through ROSdependent and caspase- and JNK-mediated pathways. Toxicol Appl Pharmacol 259(3):329-337

NHMRC (2017a) National Health and Medical Research Council. Australian drinking water guidelines 6. Version 3.4. Updated October 2017. https://www.nhmrc.gov.au/sites/default/files/documents/ reports/aust-drinking-water-guidelines.pdf.

NHMRC (2017b) Water fluoridation and human health in Australia. National Health and Medical Research Council. Public Statement. https://www.nhmrc.gov.au/about-us/publications/2017public-statement-water-fluoridation-and-human-health\#block -views-block-file-attachments-content-block-1.

NRC (2006) National Research Council; Fluoride in Drinking Water: A Scientific Review of EPA's Standards. Committee on Fluoride in Drinking Water. Board on Environmental Studies and Toxicology. Division on Earth and Life Studies. The National Academy Press, Washington

NTP (1990) National Toxicology Program. NTP technical report on the toxicology and carcinogenesis studies of sodium fluoride in F344/N Rats and B6C3F1 mice (drinking water studies). Washington, DC: Department of Health, Education, and Welfare, National Toxicology Program. NTP TR 393, NIH publication no. 90-2848.

NTP (2015) National Toxicology Program. Neurobehavioral testing specifications. Research Triangle Park: National Toxicology Program. https://ntp.niehs.nih.gov/ntp/test_info/finalntp_neuro specs090415_508.pdf.

NTP (2016) National Toxicology Program. Systematic literature review on the effects of fluoride on learning and memory in animal studies. NTP Research Report 1. Research Triangle Park, NC: National Toxicology Program. 
OECD (2007) Test No. 426: Developmental Neurotoxicity Study, OECD Guidelines for the Testing of Chemicals, Section 4, OECD Publishing, Paris.

PHS (2015) U.S. Department of Health and Human Services Federal Panel on Community Water Fluoridation; U.S. Public Health Service recommendation for fluoride concentration in drinking water for the prevention of dental caries. Public Health Reports 130(4):318-331.

Pratap SV, Singh CD, Sandeep T et al (2013) A correlation between Serum Vitamin, acetylcholinesterase activity and iq in children with excessive endemic fluoride exposure in Rajasthan. India Int Res J Medical Sci 1(3):12-16

Pulungan ZSA, Sofro ZM, Partadiredja G (2018) Sodium fluoride does not affect the working memory and number of pyramidal cells in rat medial prefrontal cortex. Anat Sci Int 93(1):128-138

Razdan P, Patthi B, Kumar JK, Agnihotri N, Chaudhari P, Prasad M (2017) Effect of fluoride concentration in drinking water on intelligence quotient of 12-14-year-old children in Mathura District: a cross-sectional study. J Int Soc Prev Community Dent 7(5):252-258

Reddy PS, Pushpalatha T, Reddy PS (2007) Suppression of male reproduction in rats after exposure to sodium fluoride during early stages of development. Naturwissenschaften 94(7):607-611

Rugg-Gunn AJ, Villa AE, Buzalaf MR (2011) Contemporary biological markers of exposure to fluoride. Monogr Oral Sci 22(37-5):1

Sabour S, Ghorbani Z (2013) Developmental fluoride neurotoxicity: clinical importance versus statistical significance. Environ Health Perspect 121(3):70

Saxena S, Sahay A, Goel P (2012) Effect of fluoride exposure on the intelligence of school children in Madhya Pradesh. India J Neurosci Rural Pract 3(2):144-149

SCHER (2011) Scientific Committee on Health and Environmental Risks of the European Union; Critical review of any new evidence on the hazard profile, health effects, and human exposure to fluoride and the fluoridating agents of drinking water.

Schleyer R, Kerndorf H (1992) Die Grundwasserqualität westdeutscher Trinkwasserreserven. VCH, Weinheim

Schmidt C, Funke U (1984) Renale Fluoridausscheidung nach Belastung mit Schwarzem Tee. Z Aerztl Fortbild 78:364-367

Schwarz K, Milne DB (1972) Fluorine requirement for growth in the rat. Bioinorg Chem 1(4):331-338

Schwarze PE, Lag M, Becher R et al (2000) Role of signal transduction pathways in lung inflammatory responses. Toxicol Lett 112-113:165-170

Sebastian ST, Sunitha S (2015) A cross-sectional study to assess the intelligence quotient (IQ) of school going children aged 10-12 years in villages of Mysore district, India with different fluoride levels. J Indian Soc Pedod Prev Dent 33(4):307-311

Seraj B, Shahrabi M, Shadfar M et al (2012) Effect of high water fluoride concentration on the intellectual development of children in makoo/iran. J Dent (Tehran) 9(3):221-229

Shan KR, Qi XL, Long YG, Nordberg A, Guan ZZ (2004) Decreased nicotinic receptors in PC12 cells and rat brains influenced by fluoride toxicity-a mechanism relating to a damage at the level in post-transcription of the receptor genes. Toxicology 200(2-3):169-177

Sharma C, Suhalka P, Bhatnagar M (2018) Curcumin and resveratrol rescue cortical-hippocampal system from chronic fluorideinduced neurodegeneration and enhance memory retrieval. Int $\mathbf{J}$ Neurosci 128(11):1007-1021

Sharma C, Suhalka P, Bhatnagar M (2018) Curcumin and resveratrol rescue cortical-hippocampal system from chronic fluorideinduced neurodegeneration and enhance memory retrieval. Int $\mathbf{J}$ Neurosci 2018:1-15

Sharma P, Bhardwaj AK, Singh M, Kumar D, Sharma A, Grover A (2018) Does fluorosis affect the intelligence profile of children?
A cross sectional analysis of school children of district Una, Himachal Pradesh, India. Int J Community Med Public Health 5(3):1047-1053

Sharma P, Singh M, Kumar D, Grover A, Bhardwaj AK (2016) Effect of fluoride exposure through drinking water on the oral health status and intelligence profile of school children of District Una, Himachal Pradesh: an interim analysis. J Evol Med Dent Sci $5(102)$.

Shashi A, Kumar J (2016) Neuropathological changes in hippocampus in albino rat in fluoride toxicity. Inter J Basic and Appl Med Sc 6:17-25

Shen YW, Taves DR (1974) Fluoride concentrations in the human placenta and maternal and cord blood. Am J Obstet Gynecol 119(2):205-207

Shuhua X, Ziyou L, Ling Y, Fei W, Sun G (2012) A role of fluoride on free radical generation and oxidative stress in BV-2 microglia cells. Mediators Inflamm 2012(2-3):Article ID 102954.

Simpson E, Rao LG, Evans RM, Wilkie W, Rodger JC, Lakhani A (1980) Calcium metabolism in a fatal case of sodium fluoride poisoning. Ann Clin Biochem 17(1):10-14

Sprando RL, Collins TF, Black T, Olejnik N, Rorie J (1998) Testing the potential of sodium fluoride to affect spermatogenesis: a morphometric study. Food Chem Toxicol 36(12):1117-1124

Sprando RL, Collins TF, Black TN, Rorie J, Ames MJ, O'Donnell M (1997) Testing the potential of sodium fluoride to affect spermatogenesis in the rat. Food Chem Toxicol 35(9):881-890

Sun Z, Zhang Y, Xue X, Niu R, Wang J (2018) Maternal fluoride exposure during gestation and lactation decreased learning and memory ability, and glutamate receptor mRNA expressions of mouse pups. Hum Exp Toxicol 37(1):87-93

Susheela AK, Das TK (1988) Chronic fluoride toxicity: a scanning electron microscopic study of duodenal mucosa. J Toxicol Clin Toxicol 26(7):467-476

Susheela AK, Jain SK (1983) Fluoride-induced haematological changes in rabbits. Bull Environ Contam Toxicol 30(4):388-393

Susheela AK, Kumar A (1991) A study of the effect of high concentrations of fluoride on the reproductive organs of male rabbits, using light and scanning electron microscopy. J Reprod Fertil 92(2):353-360

Sutton M, Kiersey R, Farragher L, Long J (2015) Health effects of water fluoridation. An evidence review. Health Research Board, Ireland. https://www.hrb.ie/fileadmin/publications_files/Healt h_Effects_of_Water_Fluoridation.pdf.

Tang S, Zhang S, Chen W et al (2017) Effects of fluoride on autophagy level in human neuroblastoma SH-SY5Y cells. Wei Sheng Yan Jiu 46(3):472-480

Taves DR (1983) Dietary intake of fluoride ashed (total fluoride) v. unashed (inorganic fluoride) analysis of individual foods. Br J Nutr 49(3):295-301

Taves DR, Forbes N, Silverman D, Hicks D (1983) Inorganic fluoride concentrations in human and animal tissues. Fluorides: Effects on Vegetation, Animals and Humans Ed Shupe J, Peterson, H, Leone, N Paragon Press, Salt Lake City, Utah, USA:189-193.

Teng Y, Zhang J, Zhang Z, Feng J (2018) The effect of chronic fluorosis on calcium ions and CaMKIIalpha, and c-fos expression in the rat hippocampus. Biol Trace Elem Res 182(2):295-302

Tu W, Zhang Q, Liu Y et al (2018) Fluoride induces apoptosis via inhibiting SIRT1 activity to activate mitochondrial p53 pathway in human neuroblastoma SH-SY5Y cells. Toxicol Appl Pharmacol 347:60-69

Villa A, Anabalon M, Zohouri V, Maguire A, Franco AM, Rugg-Gunn A (2010) Relationships between fluoride intake, urinary fluoride excretion and fluoride retention in children and adults: an analysis of available data. Caries Res 44(1):60-68 
Wang J, Zhang Y, Guo Z et al (2018) Effects of perinatal fluoride exposure on the expressions of miR-124 and miR-132 in hippocampus of mouse pups. Chemosphere 197:117-122

Wei N, Li Y, Deng J, Xu S, Guan Z (2014) The effects of comprehensive control measures on intelligence of school-age children in coal-burning borne endemic fluorosis areas. Chin J Endem 33(3):320-322

Whitford GM (1990) The physiological and toxicological characteristics of fluoride. J Dent Res 69(2):539-549 (Discussion 556-547)

Whitford GM (1996) Soft tissue distribution of fluoride. In: The Metabolism and Toxicity of Fluoride. Monogr Oral Sci. Myers H.M. (Ed); Basel, Karger, vol 16.

Whitford GM, Pashley DH, Reynolds KE (1979) Fluoride tissue distribution: short-term kinetics. Am J Physiol 236(2):F141-F148

Whitford GM, Sampaio FC, Pinto CS, Maria AG, Cardoso VE, Buzalaf MA (2008) Pharmacokinetics of ingested fluoride: lack of effect of chemical compound. Arch Oral Biol 53(11):1037-1041

WHO (2011) World Health Organization. Guidelines for drinkingwater quality. Fourth edition. https://www.who.int/water_sanit ation_health/publications/2011/dwq_guidelines/en/.

WHO (2017) Guidelines for drinking-water quality. Fourth Edition incorporating the first Addendum. https://apps.who.int/iris/bitst ream/handle/10665/254637/9789241549950-eng.pdf?seque nce $=1$.

Xia T, Zhang M, He WH, He P, Wang AG (2007) Effects of fluoride on neural cell adhesion molecules mRNA and protein expression levels in primary rat hippocampal neurons. Zhonghua Yu Fang Yi Xue Za Zhi 41(6):475-478

Xu B, Xu Z, Xia T et al (2011) Effects of the Fas/Fas-L pathway on fluoride-induced apoptosis in SH-SY5Y cells. Environ Toxicol 26(1):86-92

Xu Z, Xu B, Xia T et al (2013) Relationship between intracellular Ca(2) (+) and ROS during fluoride-induced injury in SH-SY5Y cells. Environ Toxicol 28(6):307-312

Yan L, Liu S, Wang C et al (2013) JNK and NADPH oxidase involved in fluoride-induced oxidative stress in BV-2 microglia cells. Mediators Inflamm 2013:895975

Yan N, Liu Y, Liu S et al (2016) Fluoride-induced neuron apoptosis and expressions of inflammatory factors by activating microglia in rat brain. Mol Neurobiol 53(7):4449-4460

Yan Q, Zhang Y, Li W, Denbesten PK (2007) Micromolar fluoride alters ameloblast lineage cells in vitro. J Dent Res 86(4):336-340

Yang L, Jin P, Wang X, Zhou Q, Lin X, Xi S (2018) Fluoride activates microglia, secretes inflammatory factors and influences synaptic neuron plasticity in the hippocampus of rats. Neurotoxicology 69:108-120

Yu X, Chen J, Li Y et al (2018) Threshold effects of moderately excessive fluoride exposure on children's health: A potential association between dental fluorosis and loss of excellent intelligence. Environ Int 118:116-124

Zhang M, Wang A, He W et al (2007) Effects of fluoride on the expression of NCAM, oxidative stress, and apoptosis in primary cultured hippocampal neurons. Toxicology 236(3):208-216

Zhang M, Wang A, Xia T, He P (2008) Effects of fluoride on DNA damage, S-phase cell-cycle arrest and the expression of NFkappaB in primary cultured rat hippocampal neurons. Toxicol Lett 179(1):1-5

Zhang S, Jiang C, Liu H et al (2013) Fluoride-elicited developmental testicular toxicity in rats: roles of endoplasmic reticulum stress and inflammatory response. Toxicol Appl Pharmacol 271(2):206-215

Zhang S, Niu Q, Gao H et al (2016) Excessive apoptosis and defective autophagy contribute to developmental testicular toxicity induced by fluoride. Environ Pollut 212:97-104

Zhang S, Zhang X, Liu H et al (2015) Modifying effect of COMT gene polymorphism and a predictive role for proteomics analysis in children's intelligence in endemic fluorosis area in Tianjin. China Toxicol Sci 144(2):238-245

Zhang S, Zheng X, Sun Y, Wang Y, Zhang Z (2015) Alterations in oxidative stress and apoptosis in cultured PC12 cells exposed to fluoride. Fluoride 48(3):213-222

Zhao L, Zhang S, An X et al (2015) Sodium fluoride affects dna methylation of imprinted genes in mouse early embryos. Cytogenet Genome Res 147(1):41-47

Zhao Q, Niu Q, Chen J et al (2019) Roles of mitochondrial fission inhibition in developmental fluoride neurotoxicity: mechanisms of action in vitro and associations with cognition in rats and children. Arch Toxicol 93(3):709-726

Zhu JQ, Si YJ, Cheng LY et al (2014) Sodium fluoride disrupts DNA methylation of $\mathrm{H} 19$ and $\mathrm{Peg} 3$ imprinted genes during the early development of mouse embryo. Arch Toxicol 88(2):241-248

Publisher's Note Springer Nature remains neutral with regard to jurisdictional claims in published maps and institutional affiliations.

\section{Affiliations}

\section{Sabine Guth ${ }^{1}$ - Stephanie Hüser ${ }^{1} \cdot$ Angelika Roth $^{1} \cdot$ Gisela Degen $^{1} \cdot$ Patrick Diel $^{2} \cdot$ Karolina Edlund $^{1}$. Gerhard Eisenbrand ${ }^{3} \cdot$ Karl-Heinz Engel $^{4} \cdot$ Bernd Epe $^{5} \cdot$ Tilman Grune $^{6} \cdot$ Volker Heinz $^{7} \cdot$ Thomas Henle $^{8}$. Hans-Ulrich Humpf ${ }^{9} \cdot$ Henry Jäger ${ }^{10} \cdot$ Hans-Georg Joost ${ }^{11}$. Sabine E. Kulling ${ }^{12}$. Alfonso Lampen ${ }^{13} \cdot$ Angela Mally $^{14}$. Rosemarie Marchan ${ }^{1}$. Doris Marko ${ }^{15}$. Eva Mühle ${ }^{1}$. Michael A. Nitsche ${ }^{16,17}$. Elke Röhrdanz ${ }^{18}$. Richard Stadler ${ }^{19}$. Christoph van Thriel ${ }^{1}$. Stefan Vieths ${ }^{20} \cdot$ Rudi F. Vogel $^{21} \cdot$ Edmund Wascher $^{22} \cdot$ Carsten Watzl $^{23}$. Ute Nöthlings ${ }^{24}$. Jan G. Hengstler ${ }^{1}$}

Ute Nöthlings noethlings@uni-bonn.de

$\triangle$ Jan G. Hengstler hengstler@ifado.de

1 Department of Toxicology, Leibniz Research Centre for Working Environment and Human Factors (IfADo), Dortmund, Germany
2 Department of Molecular and Cellular Sports Medicine, Institute of Cardiovascular Research and Sports Medicine, German Sport University Cologne, Cologne, Germany

3 Kühler Grund 48/1, 69126 Heidelberg, Germany

4 Department of General Food Technology, School of Life Sciences, TU Munich, Freising, Germany 
5 Institute of Pharmacy and Biochemistry, University of Mainz, Mainz, Germany

6 Department of Molecular Toxicology, German Institute of Human Nutrition (DIfE), Nuthetal, Germany

7 German Institute of Food Technologies (DIL), Quakenbrück, Germany

8 Department of Food Chemistry, TU Dresden, Dresden, Germany

9 Institute of Food Chemistry, Westfälische Wilhelms-Universität Münster, Münster, Germany

10 Institute of Food Technology, University of Natural Resources and Life Sciences (BOKU), Vienna, Austria

11 Department of Experimental Diabetology, German Institute of Human Nutrition (DIfE), Nuthetal, Germany

12 Department of Safety and Quality of Fruit and Vegetables, Max Rubner-Institut, Federal Research Institute of Nutrition and Food, Karlsruhe, Germany

13 Department of Food Safety, Bundesinstitut für Risikobewertung (BfR), Berlin, Germany

14 Department of Toxicology, University of Würzburg, Würzburg, Germany

15 Department of Food Chemistry and Toxicology, Faculty of Chemistry, University of Vienna, Vienna, Austria
16 Department of Psychology and Neurosciences, Leibniz Research Centre for Working Environment and Human Factors (IfADo), Dortmund, Germany

17 Department of Neurology, University Medical Hospital Bergmannsheil, Ruhr-University, Bochum, Germany

18 Department of Experimental Pharmacology and Toxicology, Federal Institute for Drugs and Medical Devices (BfArM), Bonn, Germany

19 Institute of Food Safety and Analytic Sciences, Nestlé Research Centre, Lausanne, Switzerland

20 Paul-Ehrlich-Institut, Langen, Germany

21 Lehrstuhl für Technische Mikrobiologie, TU Munich, Freising, Germany

22 Department of Ergonomics, Leibniz Research Centre for Working Environment and Human Factors (IfADo), Dortmund, Germany

23 Department of Immunology, Leibniz Research Centre for Working Environment and Human Factors (IfADo), Dortmund, Germany

24 Department of Nutrition and Food Sciences, Nutritional Epidemiology, Rheinische Friedrich-Wilhelms University Bonn, Bonn, Germany 